University of Michigan Law School

University of Michigan Law School Scholarship Repository

Articles

Faculty Scholarship

2011

\title{
Do Sex Offender Registration and Notification Laws Affect Criminal Behavior?
}

\author{
J.J.Prescott \\ University of Michigan Law School, jprescott@umich.edu \\ Jonah E. Rockoff \\ Columbia University, jonah.rockoff@columbia.edu
}

Available at: https://repository.law.umich.edu/articles/82

Follow this and additional works at: https://repository.law.umich.edu/articles

Part of the Criminal Law Commons, Law and Society Commons, and the Legislation Commons

\section{Recommended Citation}

Prescott, J. J. "Do Sex Offender Registration and Notification Laws Affect Criminal Behavior?" J. E. Rockoff, co-author. J. L. \& Econ. 54, no. 1 (2011): 161-206.

This Article is brought to you for free and open access by the Faculty Scholarship at University of Michigan Law School Scholarship Repository. It has been accepted for inclusion in Articles by an authorized administrator of University of Michigan Law School Scholarship Repository. For more information, please contact mlaw.repository@umich.edu. 


\title{
Do Sex Offender Registration and Notification Laws Affect Criminal Behavior?
}

\author{
J.J. Prescott University of Michigan \\ Jonah E. Rockoff Columbia University
}

\begin{abstract}
Sex offenders have become targets of some of the most far-reaching and novel crime legislation in the United States. Two key innovations have been registration and notification laws, which, respectively, require that offenders provide identifying information to law enforcement and mandate that this information be made fully public. We study how registration and notification affect the frequency and incidence across victims of reported sex offenses. We present evidence that registration reduces the frequency of reported sex offenses against local victims (for example, neighbors) by keeping police informed about local sex offenders. Notification also appears to reduce crime, not by disrupting the criminal conduct of convicted sex offenders, but by deterring nonregistered offenders. We find that notification may actually increase recidivism. This latter finding, consistent with the idea that notification imposes severe costs that offset the benefits to offenders of forgoing criminal activity, is significant, given that notification's purpose is recidivism reduction.
\end{abstract}

\section{Introduction}

Criminal recidivism poses a serious risk to public safety. As many as two-thirds of released inmates return to prison within a few years (Langan and Levin 2002), and data from the National Corrections Reporting Program show that approx-

We thank Charles Calomiris, Ray Fisman, Brandon Garrett, Matthew Gentzkow, Sam Gross, Jim Hines, Jill Horwitz, Amit Khandelwal, Rick Lempert, Justin McCrary, Rob Mikos, Tom Miles, Daniel Paravisini, John Pottow, Doug Staiger, Sonja Starr, Betsey Stevenson, and Toni Whited for their comments and suggestions, as well as seminar participants at Brooklyn Law School, the University of Chicago Law School, Columbia Business School, University of Houston, Harvard Law School, Northwestern Law School, Rice University, Stanford Law School, Syracuse University, the University of Virginia Law School, the 2007 American Law and Economics Association Meeting, the 2007 Canadian Law and Economics Meetings, the 2008 Maryland Crime and Population Dynamics Con- 
imately 40 percent of all criminals sent to U.S. prisons over the last 20 years were already convicted felons. Recently, victims' advocates and others have argued that persons convicted of sex offenses are highly likely to reoffend by committing another sex crime (Langan, Schmitt, and Durose 2003; Vásquez, Maddan, and Walker 2008). Although criminal behavior typically declines steeply with age after an individual's early 20s, the decline for sex offenses may be more gradual (Hanson 2002). Partly for these reasons, and because of certain high-profile crimes that occurred in the late 1980s and early 1990s, sex offenders have become the focus of considerable legislation and public spending aimed at reducing their recidivism.

In the 1990s, two types of laws targeting sex offender behavior proliferated across the United States. A federal mandate in 1994 (the Jacob Wetterling Act, named after the victim of a crime in Minnesota) directed states to create registries containing information about convicted sex offenders for use by law enforcement. In 1996, another federal law (Megan's Law, named after Megan Kanka, a victim in New Jersey) began to require that states provide public notification of the identities and addresses of sex offenders to local residents or other at-risk groups. The basic motivations for registration and notification, respectively, were to aid law enforcement in supervising and apprehending sex offenders who might recidivate and to help local households protect themselves by monitoring and avoiding offenders in their neighborhoods.

Despite their now widespread use, it is unclear whether sex offender registration and notification laws have reduced criminal behavior by sex offenders or whether these laws have advanced any other criminal justice goals (such as increasing the probability of an arrest, conditional on the report of a sex offense). It is also unknown whether sex offenders respond to these laws in possibly unexpected or adverse ways - for example, by selecting different rather than fewer victims. The answers to these questions are important not only for evaluating the costs and benefits of registration and notification laws but also for understanding how an important group of known criminals responds to changes in legal sanctions. ${ }^{1}$

The first studies that sought to measure the impact of registration and notification laws compared the recidivism rates of offenders released just before and after registration and notification laws became effective in Iowa and Wash-

ference, the 2008 Conference on Empirical Legal Studies, and the National Bureau of Economic Research Working Group on the Economics of Crime. Reid Aronson, Erik Johnson, Rembrand Koning, Nicholas Lee, Elias Walsh, Oliver Welch, and Julia Zhou provided excellent research assistance. Prescott gratefully acknowledges the John M. Olin Center for Law and Economics at the University of Michigan Law School for supporting this project. Rockoff thanks the Paul Milstein Center for Real Estate at Columbia Business School for research support.

${ }^{1}$ Empirical work provides some support for the claim that criminals in general react to changes in expected punishment (Levitt 1998; Kessler and Levitt 1999; Nagin 1998). However, it is unclear whether this is true for all types of individuals (see McCrary and Lee [2005] for information on juvenile offenders), and whether these results extend to sex offenders in particular is unknown (Bachman, Paternoster, and Ward 1992). 
ington (Schram and Milloy 1995; Adkins, Huff, and Stageberg 2000). Although neither study found a statistically significant difference in the frequency of subsequent arrests for sex offenses between these two groups, both studies relied on small samples of offenders. More recent studies examine the relationship between the timing of legislation and changes in the annual frequency of sex offenses across states, using data from the Federal Bureau of Investigation's (FBI's) Uniform Crime Reporting (UCR) Program (Shao and Li 2006; Agan 2007; Vásquez, Maddan, and Walker 2008). Taken together, these studies find little evidence that such laws have had any meaningful influence on the overall number of sex offenses. ${ }^{2}$

Although we also use the timing of changes in state laws to study the impact of sex offender registration and notification on criminal behavior, we are able to offer new evidence regarding a number of different questions because our analysis differs significantly from previous research in both the data we use and the methodology we employ. First, we conducted extensive research into the sex offender legislation of various states and found that prior studies had used incorrect legal dates or had mischaracterized many of these laws. Understanding the timing and scope of this body of law is not easy, in part because sex offender laws have evolved over time as a result of legislative amendments and judicial decisions. ${ }^{3}$ We also take advantage of information on the exact dates when laws became effective by using monthly data and allowing for variation in crime frequency within years, in contrast to earlier work using annual data.

Second, unlike existing research, our analysis distinguishes between sex offender registration laws and sex offender notification laws. Notification laws mandate the dissemination of information about sex offenders (for example, criminal history, physical description, and home address) to the public. Registration laws, by contrast, require that sex offenders provide these specifics to some division of government (such as the local police), but the information is otherwise kept confidential. While registration requirements are intended solely to aid law enforcement in monitoring offenders and apprehending known recidivists, notification laws aim to reduce crime through greater public awareness of nearby offenders, which facilitates offender avoidance, public monitoring, and public identification of a suspect in the event that a convicted sex offender commits a new crime (Prentky 1996; Pawson 2002; Levenson and D'Amora 2007). We also differentiate among the various features of notification laws,

\footnotetext{
${ }^{2}$ Only Shao and Li (2006) report any evidence that offender registration laws caused a statistically significant reduction in sex offenses. However, their findings are sensitive to empirical specification, and they group registration and notification laws together as a single treatment. Agan (2007) offers some evidence that posting sex offender information on the Internet reduces the number of arrests for sex offenses, but her results are similarly sensitive and are open to alternative interpretations.

${ }^{3}$ We describe the history of sex offender registration and notification laws in Section 2 and provide basic information about these enactments in Tables A1 and A2.
} 
including public access to a paper registry, public access to a searchable Internet site, or active community notification. ${ }^{4}$

Third, we use variation in the number of offenders who are actually registered with authorities to identify different ways that registration and notification laws might influence criminal behavior. For instance, notification laws were designed to reduce recidivism by making people aware of nearby sex offenders, but notification may also reduce crime by enhancing the punishment for first-time or nonregistered sex offenders, whose crimes and personal information will be made public if they are caught and convicted. To distinguish these possibilities, we exploit the fact that although a notification law should have little effect on recidivism when a registry is empty, any effect on the behavior of nonregistered individuals should be invariant to registry size.

Finally, we examine the impact of these laws on the offender-victim relationship mix in addition to the effect, if any, on the overall frequency of reported sex offenses. Neither registration nor notification was intended to vary the incidence of sex offenses across different types of victims, but some observers suspect that notification laws might simply displace crime by changing the population of victims that sex offenders target (see Prentky 1996; Filler 2001). We also study changes in the probabilities that an arrest is made when a sex offense is reported and that the offense is not prosecuted, despite arrest, because the victim refuses to cooperate or the prosecution declines to pursue the case.

We find evidence that actual registration of released sex offenders is associated with a significant decrease in crime. This result is in line with predictions from a simple model of criminal behavior in which providing information on offenders to local authorities increases monitoring and therefore the likelihood of punishment for recidivism. Moreover, the decrease in the overall frequency of reported sex offenses associated with registration is primarily due to reductions in attacks against local victims who are known to an offender (namely, friends, acquaintances and neighbors). The frequency of sex offenses committed by strangers appears to be unaffected by registration, indicating little substitution by sex offenders from local to more distant victims.

We also find that the implementation of a notification law, regardless of the number of registered offenders, is associated with a reduction in the frequency of sex offenses. One potential explanation for this effect, also consistent with our model, is that notification deters potential (nonregistered) offenders by increasing the punishment for committing a sex crime. Importantly, we detect no evidence that notification laws (as opposed to registration laws) curtail crime by reducing recidivism among convicted sex offenders; the estimated effect of notification is actually weaker when a state applies the law to a large number

\footnotetext{
${ }^{4}$ Shao and Li (2006) do not differentiate between notification and registration laws. Vásquez, Maddan, and Walker (2008) explicitly state that they examine both registration and notification laws but do not distinguish between the two in their empirical work. Agan (2007), on the other hand, recognizes the distinction with respect to availability of registry information on the Internet but nevertheless does not include or consider other kinds of notification.
} 
of offenders. This finding is potentially consistent with a number of explanations. However, as we argue below, the evidence on balance supports the existence of a relative utility effect in which convicted sex offenders become more likely to commit crimes when their information is made public because the associated psychological, social, or financial costs make crime-free life relatively less attractive.

The rest of the paper proceeds as follows. In Section 2, we summarize the variation in the timing and scope of state registration and notification laws. Section 3 illustrates the potential effects of registration and notification using a simple model of criminal behavior and explains our basic empirical methodology. Section 4 describes our data. We present our results in Section 5 and robustness checks in Section 6. We conclude in Section 7.

\section{The Evolution of Sex Offender Registration and Notification Laws}

To characterize sex offender registration and notification laws properly for our empirical work, we painstakingly researched the evolution of these laws in states covered in the 1990s by National Incident-Based Reporting System (NIBRS) data, which we use in our analysis. ${ }^{5}$ We divide the legal changes that we study into four categories: registration, public access to a paper registry, Internet registry availability, and active community notification.

Registration requires that sex offenders provide authorities with identifying information upon release from custody or probation. Until notification laws were enacted, this information was treated as confidential. Police increase surveillance of registered offenders and can more easily locate, investigate, and apprehend them when necessary. The remaining three categories of laws—public access to a paper registry, Internet registry availability, and active community notification-are designed to make information about offenders available to the public rather than to assist the police directly. The public can, in theory, reduce sex offender recidivism by avoiding convicted offenders and reporting suspicious behavior.

Since the late 1980s and early 1990s, states have typically progressed from using basic registration laws to relying on more restrictive and varied forms of public access and from restrictive public access to publication of sex offender

\footnotetext{
${ }^{5}$ See the Appendix. Determining accurate effective dates proved difficult. When we compare our dates to those used by Shao and Li (2006), Agan (2007), and Vásquez, Maddan, and Walker (2008), we find a low rate of agreement. Among the 50 states and the District of Columbia, there are only 12 instances (14 instances) in which all studies agree on the exact date (calendar year) that registration became effective. For example, Utah's first generally applicable sex offender registry became effective May 10, 1983. Shao and $\mathrm{Li}$ (2006) use May 19, 1987, a date that we cannot locate in legislative history but that is close to the April 27 effective date of a 1987 law that recodified and amended the registration law. Agan (2007) uses July 1, 1984, which likely refers to a 1984 law that also amended the original 1983 enactment, but the effective date for that law was February 16, 1984. Vásquez, Maddan, and Walker (2008) use 1996, when Utah passed a notification law granting public access to registry information.
} 


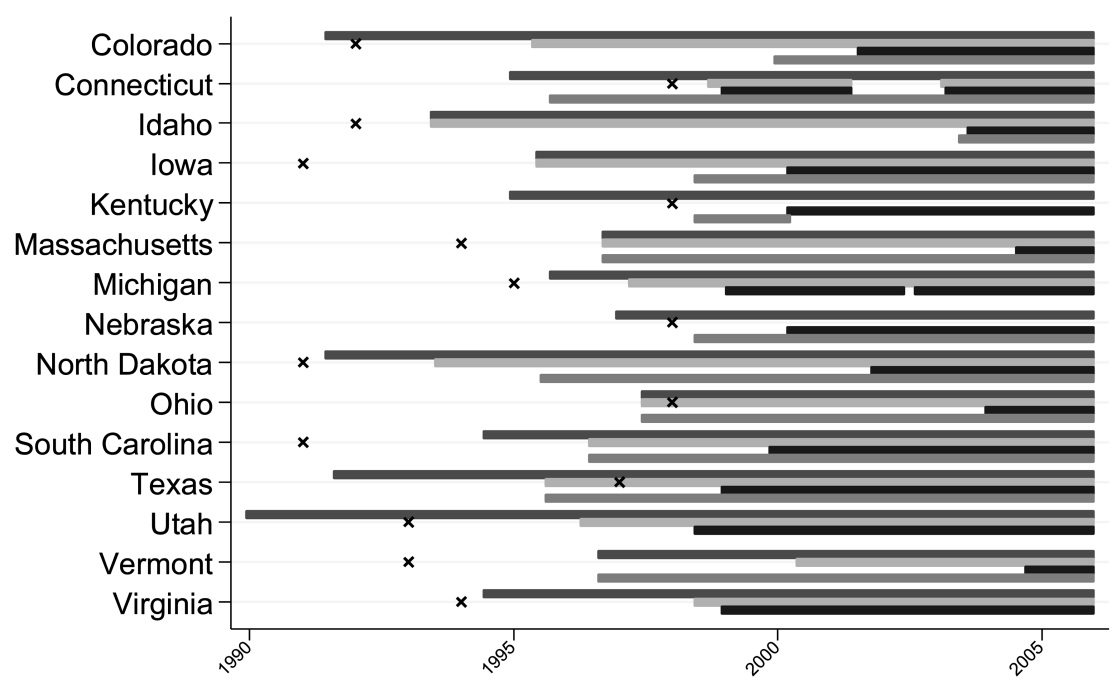

$\begin{array}{ll}\text { Registration Effective } & \text { Public Access (Paper) } \quad \text { Internet Registry } \\ \text { Active Notification } & \times \text { Year Joined NIBRS }\end{array}$

Figure 1. Effective dates of registration and notification laws in 15 early National IncidentBased Reporting System (NIBRS) states.

registration information on the Internet. ${ }^{6}$ Many states also implemented active community notification regimes, such as announcing the release or arrival of sex offenders in local newspapers. ${ }^{7}$ At each new stage, states also determined whether to make their laws or the changes to their laws retroactive in their application. Retroactivity provisions specify which offenders are subject to these laws in terms of the timing of an offender's conviction or release from custody. ${ }^{8}$ We use all of this cross-state variation-in exact timing, scope, retroactivity, and registry size-to identify the causal effects of registration and notification laws.

Figure 1 shows the effective dates of registration laws, laws allowing public

\footnotetext{
${ }^{6}$ Sex offender Web registries typically allow the public to search for offenders using an individual's name or alias or to search for all offenders living near a specific address.

${ }^{7}$ Other examples of active community notification include personal visits made by police officers or letters sent to former victims or other persons considered to be at risk, as well as opt-in provisions, which allow citizens to request notification if a certain sex offender or one satisfying certain conditions is released or moves.

${ }^{8}$ For example, the registration law in Massachusetts, effective October 1996, required anyone convicted of a qualifying sex offense on or after August 1, 1981, to register. As a result, nearly 8,000 offenders were registered when the registry became effective (Boston Globe 1996). Other states made their laws prospective. For instance, Michigan's registration law, effective October 1, 1995, required registration of individuals convicted or released on or after that date. As a result, when the law became effective, Michigan's registry was empty.
} 
access to a paper registry, and laws requiring active community notification, as well as the dates on which substantially complete Internet registries became publicly accessible for our NIBRS states (see also Tables A1 and A2) and the year in which agencies from each state began reporting to NIBRS. Although sex offender laws have evolved in a similar fashion from state to state, Figure 1 demonstrates that the timing and content of these laws vary considerably. For example, Iowa began registration and (limited) public access simultaneously in 1995 but did not have any form of active notification until 1998 or an Internet site until 2000. Texas, by contrast, began registration in 1991, instituted public access and active notification in 1995, and launched an Internet site in 1999.

Endogeneity in the timing of the adoption of these laws is unlikely to be a problem for several reasons. First, unlike with most criminal laws, where rising crime rates might lead to increases in penalties or police spending, many state sex offender laws were passed quickly in response to one or two well-publicized and usually gruesome incidents. Indeed, many sex offender enactments are named after the victim who sparked the legislative effort, and sex offense rates (like rates of other crimes) actually declined in the 1990s, the period during which most of these laws were passed. Second, federal mandates passed in 1994 and 1996 (motivated in part by specific crimes against individual children in Minnesota and New Jersey) required states to institute registration and notification regimes. These federal laws left states with discretion as to substance and timing but had minimum requirements and imposed deadlines. Finally, the timing of the state laws was also partly dictated by preexisting legislative schedules that were unrelated to offense trends (for example, the North Dakota and Texas legislatures meet regularly only once every 2 years). ${ }^{9}$

\section{Conceptual Model and Empirical Framework}

To generate testable hypotheses and to aid in the interpretation of our empirical results, we consider a simple model of criminal behavior. Criminal offenses committed by individual $i$ against victim $j$ are governed by a victim-specific probability of punishment $\left(p_{i j}\right)$ and targeting costs $\left(c_{i j}\right)$, a level of punishment if convicted $\left(f_{i}\right)$, and utility from committing crime relative to engaging in legal behavior $\left(u_{i}\right)$ that is invariant across victims. ${ }^{10}$ Victim specifics are important in

\footnotetext{
${ }^{9}$ Whether a sex offender law is made retroactive is also unlikely to be endogenous to crime rates. Criminal laws with retroactive features can violate the U.S. Constitution or its state counterparts. The decision whether to make a law retroactive in any particular state turns in significant part on governing judicial opinions in that state.

${ }^{10}$ This model is adapted from the structure of Becker (1968). The utility term is an analogue to Becker's (1968, p. 177) concept of the individual's "willingness to commit an illegal act." The assumption that the relative utility of criminal behavior is invariant across victims may not be true in a strict sense (a particular offender, for example, may prefer targeting a stranger to a neighbor, conditional on actual costs), but any variation can be reinterpreted as a difference in victim-specific targeting costs. In any event, because we focus on the changes in these terms caused by registration and notification laws, the assumption is not critical to motivating or interpreting our empirical work.
} 
this model because the sex offender laws that we consider were intended to make it difficult for offenders to victimize people in their vicinity-neighbors, acquaintances, and the like. By assumption, the number of offenses is increasing in the relative utility of crime commission $\left(u_{i}\right)$ (or decreasing in the relative attractiveness of choosing legal behavior) and decreasing in the costs of targeting a victim $\left(c_{i j}\right)$, punishment probability $\left(p_{i j}\right)$, and punishment severity $\left(f_{i}\right)$ :

$$
O_{i j}=O_{i j}\left(c_{i j}, p_{i j}, f_{i}, u_{i}\right) \text {. }
$$

Registration and notification laws are likely to influence the number of offenses through several specific channels. Registration may enhance the ability of police to monitor and apprehend registered sex offenders, increasing the probability of punishment $\left(p_{i j}\right)$ for registrants - in particular, when registered offenders target neighbors because local police will be more likely to connect victims to known offenders. Registration may also affect forward-looking, nonregistered individuals because punishment $\left(f_{i}\right)$ now includes a higher future probability of detection. ${ }^{11}$ However, as long as registry information remains confidential, registration alone should not alter the costs of targeting victims $\left(c_{i j}\right)$ or the utility of committing a crime $\left(u_{i}\right)$.

Notification-via physical access to registry information, an Internet registry, or active notification-may also affect criminal behavior. With a notification law in place, punishment for sex offenses includes the public airing of a sex offender's personal information and criminal history. This publicity can lead to negative consequences for sex offenders, including loss of employment, housing, or social ties; harassment; and psychological costs such as increased stress, loneliness, and depression (see Zevitz and Farkas 2000a; Tewksbury 2005; Levenson and Cotter 2005). Consequently, for nonregistered sex offenders, the passage of a notification law increases punishment severity $\left(f_{i}\right)$ because any subsequent sex offense conviction would newly subject such offenders to this sort of notoriety. ${ }^{12}$

By contrast, registered sex offenders living under notification regimes, whatever their behavior, already suffer from these kinds of publicity costs. Although committing another offense may prolong an offender's registration term by adding time in the distant future - the federal minimum registration period is 10 yearsmany states have lifetime registration for violent sex offenders, and some states have lifetime registration for virtually all sex offenses. Moreover, the consequences of notification (for example, difficulty of finding employment) may cause registered sex offenders to commit more crimes than they would have otherwise (Freeman-Longo 1996; Prentky 1996; Winick 1998; Presser and Gun-

\footnotetext{
${ }^{11}$ Implementing a registry might also decrease the probability of punishment $\left(p_{i j}\right)$ for first-time offenders if the police shift resources toward monitoring registrants and away from detection of new crimes. Unfortunately, we cannot determine whether this occurs.

${ }^{12}$ We use the terms "nonregistered" and "potential" offenders to refer to individuals who have never committed a sex offense, individuals who have committed sex offenses but who have never been convicted, and individuals who were previously convicted of sex offenses but who, for some reason, are not required to register (for example, offenders released before the passage of a nonretroactive registration law).
} 
nison 1999; Edwards and Hensley 2001). In the context of our model, punishment $\left(f_{i}\right)$ would remain constant (or increase slightly) for registered sex offenders, while the relative utility of criminal behavior $\left(u_{i}\right)$ would increase because lawabiding behavior would typically involve more harassment, stress, loneliness, and unemployment. ${ }^{13}$

In addition, by allowing local residents, friends, and acquaintances to identify and avoid registered sex offenders, notification may increase the costs for these offenders of targeting this particular subset of potential victims $\left(c_{i j}\right)$. Indeed, a major motivation for the passage of the federal Megan's Law was the belief that Megan Kanka would have avoided her fate had her parents been notified of her eventual attacker's presence in the neighborhood. However, it is unclear whether an increase in the costs of targeting a subset of potential victims reduces the overall number of sex offenses. Notification may instead "accomplish nothing more than changing the neighborhood in which the offender looks for victims" (Prentky 1996, p. 295), simply displacing crime rather than reducing it. ${ }^{14}$

Although we lack information on whether any particular crime in our data was committed by a registered sex offender, we can use the ideas described above to identify and distinguish the different effects of registration and notification regimes on the criminal behavior of both registered and nonregistered offenders by using variation in the number of individuals on state sex offender registries. Specifically, any effect of registration on the overall frequency of crime due to an increase in the probability of punishment should be small when relatively few offenders are registered and should grow in magnitude with the size of the registry. The potential impact of registration on the punishment level $\left(f_{i}\right)$ for forward-looking, nonregistered individuals, however, would not depend (or would depend very little) on the size of the registry. Likewise, notification may increase the level of punishment $\left(f_{i}\right)$ facing nonregistered sex offenders, reducing aggregate crime irrespective of the size of the sex offender registry. ${ }^{15}$ Notification may also have several offsetting effects on the behavior of registered sex offenders by increasing the costs of targeting local victims $\left(c_{i j}\right)$, increasing the probability of punishment for local crimes $\left(p_{i j}\right)$, slightly increasing the level of punishment

${ }^{13}$ Although we conceive of these burdens on offenders as increasing the relative utility of criminal behavior, one could also think of them as reducing punishment levels because they make life in prison seem relatively more attractive. Either interpretation of a higher $u_{i}$ leads to an increase in the number of offenses committed by a registrant in our model.

${ }^{14}$ In addition to increasing the costs of targeting local victims, notification may increase vigilance and the monitoring of a registered sex offender's actions in his neighborhood. This communitypolicing effect (Lieb 1996) could increase the likelihood of apprehension if an offender attacks a local victim. Again, if the likelihood of punishment increases only for crimes against local victims, offenders may simply offend in other neighborhoods. Crime displacement has been an important consideration in other empirical research on the response of criminals to changes in their environments (Jacob, Lefgren, and Moretti 2004; Di Tella and Schargrodsky 2004; Iyengar 2007).

${ }^{15}$ This response may in turn affect the distribution of offender-victim relationships if an offender's probability of punishment is correlated with his relationships to victims. For example, the reporting rate to police and, hence, the probability of punishment may be lower for sex crimes committed against children by members of their family (Filler 2001). 
$\left(f_{i}\right)$, and increasing the relative utility of crime commission $\left(u_{i}\right)$. The overall tally of these effects for the level of crime is indeterminate, but, again, any net impact is likely to grow in magnitude with registry size.

To conduct this analysis, we estimate the following reduced-form equation:

$$
\begin{aligned}
\text { Crime }_{j t}= & \alpha_{j}+\gamma_{t}+\lambda X_{j t} \\
& +\sum_{s} D_{j}^{s}\left[\beta_{0} \mathbf{R g}_{t}^{s}+\beta_{1} \mathbf{N t}_{t}^{s}+\left(\beta_{2} \mathbf{R g}_{t}^{s}+\beta_{3} \mathbf{N t}_{t}^{s}\right) \times \operatorname{RgSize}_{j t}\right]+\varepsilon_{j t} .
\end{aligned}
$$

Crime $_{j t}$ is a measure of crime frequency (for example, offenses per 10,000 people) for reporting area $j$ in time period $t$. A reporting area fixed effect $\left(\alpha_{j}\right)$ captures any persistent heterogeneity in crime across areas, and a time effect $\left(\gamma_{t}\right)$ accounts for secular changes in crime over time. We control for time-varying reporting area characteristics $\left(X_{j t}\right)$ that are likely to influence crime levels. Vectors $\mathbf{R g}_{t}^{s}$ and $\mathbf{N t}_{t}^{s}$ indicate whether state $s$ had a sex offender registry or a notification law in place during time period $t$, and $\operatorname{RgSize}_{j t}$ is a measure of registry size in area $j$ in time period $t$. The indicator $D_{j}^{s}$ denotes that reporting area $j$ is located in state $s$.

The coefficient $\beta_{0}$ represents the deterrence effect of a registration law on the criminal behavior of nonregistered offenders and should be negative if the requirement to register that follows a first sex offense conviction makes punishment for subsequent crimes more likely. ${ }^{16}$ A stronger prediction of our model, however, is that $\beta_{2}$ should be negative. Registration reduces crime by increasing the probability that each registered sex offender is punished if he commits another crime and therefore should reduce crime by more when there are more registered sex offenders - that is, when the registry is large. ${ }^{17}$

The coefficient $\beta_{1}$ captures the effect of notification on nonregistered sex offender behavior and should also be negative, reflecting the significant threat that the consequences of notification pose to the well-being of nonregistered

\footnotetext{
${ }^{16}$ Registration laws in Massachusetts and South Carolina retroactively affected large numbers of released offenders, and Texas and Utah joined the National Incident-Based Reporting System (NIBRS) well after their registries had begun. As a consequence, the identification of $\beta_{0}$-the effect on crime frequency of a registry with no registrants-relies on less in-sample variation than the number of states in our sample suggests.

${ }^{17}$ In theory, registry size could influence the behavior of nonregistered offenders if they respond either to contemporaneous registry size or the expected size of the registry in the future. In that case, $\beta_{2}$ and $\beta_{3}$ would embody mixes of deterrence and recidivism reduction. Potential offenders might believe that resources devoted to tracking offenders would outpace or, instead, lag behind the growth in registry size; that a large registry would overwhelm the public with information or, alternatively, make the public more aware; or that growth in the number of registrants would reduce the stigma against sex offenders or just make it worse. We know of no evidence that potential offenders consider or are even aware of registry sizes in determining their behavior, and to us it seems improbable that more than a few of them have any such knowledge or take into account such information. Still, although we interpret $\beta_{2}$ and $\beta_{3}$ as recidivism effects, some small portion of the effects that we identify may be attributable to nonregistered offender behavior.
} 
individuals. ${ }^{18}$ By contrast, there is no clear prediction for the sign of $\beta_{3}$, given the potentially offsetting effects notification may have on the behavior of those individuals who are already subject to its requirements. Finding that $\beta_{3}$ is negative would signify that notification reduces the availability of victims and would bolster claims made by the proponents of these laws that they protect the public from sex offender recidivism. However, if offenders shift to other victims or commit more crimes because public disgrace has made criminal activity relatively more attractive than law-abiding behavior, our estimate of $\beta_{3}$ could be close to zero or even positive. ${ }^{19}$

We can also use equation (2) to examine the impact of registration and notification on the distribution of relationships between sex offenders and their victims (for example, friend, neighbor, or stranger). As a general matter, registration and notification laws apply equally to all covered sex offenses and without regard to the type of offender-victim relationship involved. Therefore, any increase in punishment for nonregistered offenders $\left(\beta_{0}\right.$ and $\left.\beta_{1}\right)$ should, all else equal, produce similar effects across all relationship types. With respect to the behavior of registered sex offenders, however, a registry's crime-reducing impact $\left(\beta_{2}\right)$ should be greater for offenses against local victims as a result of increased local monitoring, with a smaller effect for distant-relationship offenses or, potentially, a positive effect if the law merely induces substitution away from local victims. How the effect of notification laws on registered sex offenders' behavior $\left(\beta_{3}\right)$ should vary across offender-victim relationship types is unclear. If the increased cost of targeting local victims predominates, we should observe fewer crimes against local victims and either no change or an increase in the number of crimes against strangers. However, if growth in the relative utility of

\footnotetext{
${ }^{18}$ The identification of $\beta_{1}$ relies significantly on out-of-sample variation because only a few of the NIBRS states passed a statute requiring full notification at the same time as their registration law, and most states did not do so until several years after their registration laws became effective. Nevertheless, our data do include a considerable number of observations in which the number of registered offenders per 10,000 people is quite low relative to the sample mean. For example, the sample mean of registry size among observations with a full notification law in place is 17.3 offenders per 10,000 people, while the 10th percentile is approximately 5.7 offenders per 10,000 people, and the 10th percentile within each state is equal to or less than six offenders per 10,000 people in seven of the 15 NIBRS states. Our estimates suggest that enacting a notification law with this low number of registered individuals would still have a negative and statistically significant effect on the frequency of sex crime.

${ }^{19}$ One concern with the use of registry size is the potential for bias due to reverse causation because registry size is determined in part by the number of sex offenses committed in the past. In practice, however, registry size is primarily a function of how long the registry has been in existence, the degree to which the registration law applied retroactively to previously released offenders, the inclusion or exclusion of offenders convicted of less serious crimes, and overall compliance with the registration law. In addition, the lag with which new offenders are added to the registry is likely to be quite long. For individuals sent to prison in 2002 whose first listed offense was rape, sexual assault, or child molestation, the median sentence lengths were 120,72, and 68 months, respectively, and the fraction with a sentence of 1 year or less was 1.7, 2.5, and 1.8 percent, respectively (authors' calculations using data from the 2002 National Corrections Reporting Program [U.S. Department of Justice 2006]). Thus, only a very small amount of growth in registry size is due to recent convictions, and any short-run change in the frequency of sex offenses driven by other factors is unlikely to be correlated with short-run changes in registry size.
} 
crime commission is paramount, an increase in the frequency of sex offenses across all victim types seems probable because the change in the relative utility of crime commission is unlikely to be specific to victim type.

When examining arrests and dropped cases, we use incident-level data to estimate equations that are similar in form to equation (2). For example,

$$
\begin{aligned}
\text { Arrest }_{i j t}= & \alpha_{j}+\gamma_{t}+\lambda X_{i j t} \\
& +\sum_{s} D_{i}^{s}\left[\delta_{0} \mathbf{R g}_{t}^{s}+\delta_{1} \mathbf{N t}_{t}^{s}+\left(\delta_{2} \mathbf{R g}_{t}^{s}+\delta_{3} \mathbf{N t}_{t}^{s}\right) \times \operatorname{RgSize}_{i j t}\right]+\varepsilon_{i j t} .
\end{aligned}
$$

An incident in reporting area $j$ is denoted by $i$. Incident-level variables $\left(X_{i j t}\right)$ include details about the crime known to police (for example, characteristics of the victim, the offender, and their relationship; the offense type; and the number of victims and offenders involved). The other variables are incident-level analogues to the regressors in equation (2).

When predicting the effect of registration and notification laws on arrest patterns, police behavior becomes as relevant as any response by potential offenders. Neither type of law should directly influence the likelihood of arrest for nonregistered individuals $\left(\delta_{0}\right.$ and $\left.\delta_{1}\right)$ through changes in police conduct because, by definition, police do not have any special knowledge of the identities or whereabouts of these individuals and presumably are not monitoring them. ${ }^{20}$ If the punishment level $(f)$ increases, however, potential offenders may offend less, substituting away from crimes against marginal victims for which the probability of punishment $(p)$ is relatively high. This prospect suggests that any change in the likelihood of arrest $\left(\delta_{0}\right.$ and $\left.\delta_{1}\right)$ should mirror the direction of any effects of these laws on offense frequency $\left(\beta_{0}\right.$ and $\left.\beta_{1}\right)$.

The predicted impact on arrest rates for sex offenses committed by registered sex offenders is also ambiguous. Registration should increase arrest rates through enhanced monitoring and easier apprehension $\left(\delta_{2}\right)$, but registrants may respond to their registration by forgoing offenses against victims when being arrested is relatively more likely. Therefore, the effect on arrest rates should be positive if there is no change in recidivism but small if registered offenders offend less or select victims such that the probability of punishment for any crime remains low. A similar analysis applies to notification. A direct effect $\left(\delta_{3}\right)$ on registered offenders, by way of community policing, should increase the probability of arrest. However, if local victims use notification information to avoid known criminals, becoming more costly to target $(c)$, offenders may attack only that subset of local victims that ensures the probability of punishment will be sufficiently low, causing average observed arrest rates to decrease. In addition, if notification renders legal behavior relatively less attractive $(u)$, arrest probabilities

\footnotetext{
${ }^{20}$ If monitoring registrants or responding to citizen complaints about registrants becomes so expensive or time consuming that the police are not able to investigate crimes or perform other activities likely to deter crime, then nonregistered sex offenders might eventually perceive these changes and react to the reduced probability of punishment by committing more crimes.
} 
may increase as offenders become willing to commit comparatively brash crimes for which the probability of punishment was previously too great.

In general, therefore, the impact of these policies on arrest probabilities depends fundamentally on the effect of registration and notification laws on overall crime frequency. As we explain below, we find little evidence of a direct connection between these laws and our arrest variables, but the patterns that emerge from our analysis of arrest data (and of dropped cases) do serve to confirm the robustness of our offense frequency findings. ${ }^{21}$ Table 1 provides a summary of the predicted relationships between the registration and notification variables in equations (2) and (3) and the model parameters and outcomes of interest.

\section{Data}

Our primary data source, NIBRS, is part of the FBI's UCR Program but presents several opportunities for research that are unavailable with standard UCR data. First, NIBRS links information on victims, offenders, and arrestees for each incident. As a result, we can examine the impact of registration and notification laws on the relationship mix of offenders and victims and on the ability of police to secure an arrest for a reported crime, in addition to measuring the effects that these laws have on reported crime frequency. Second, the timing information for each incident is superior in NIBRS, which allows us to better exploit within-year variation in the effective dates of sex offender laws in our empirical work. Although UCR data are available by month, they only contain information on when an incident was reported, whereas NIBRS data supply the date on which an incident occurred. ${ }^{22}$

The NIBRS data do have significant limitations, however. First, like most crime data, NIBRS data contain only information on incidents recorded by police. Changes in reported crime may be driven by true changes in victimization or by changes in reporting behavior. (We return to this issue when interpreting our findings.) A second limitation is that NIBRS data started to become available

\footnotetext{
${ }^{21}$ We also examine cases that are dropped by prosecutors because of noncooperation by victims or for other reasons. This information is included in NIBRS and is of interest to us, but it is not part of our model; therefore, we leave the discussion of these issues until after we present our main results.

${ }^{22}$ If the date of the incident is not known to the police-this occurs for approximately 20 percent of sex offenses-then NIBRS reports the date on which the crime was reported. Unfortunately, NIBRS does not retain both dates, so we cannot directly measure the lag between occurrence and report. However, we can get a sense of the gap between incident and report dates by using the fact that a subset of crimes reported in NIBRS took place in a prior calendar year (that is, some crimes that occurred in year $T$ are reported in the data for year $T+1)$. We examined all sex offenses (excluding 2005) by the calendar month in which they took place and measured the fraction reported in the following year. Of the sex offenses that took place in December, 11 percent were reported the next year, while the corresponding data for November, July, and March are 7, 2, and 1 percent, respectively. Thus, although most crimes are reported within a few months of their occurrence, a nontrivial fraction are reported with considerable lag. In any event, our results are not sensitive to excluding crimes for which an incident date is unavailable.
} 


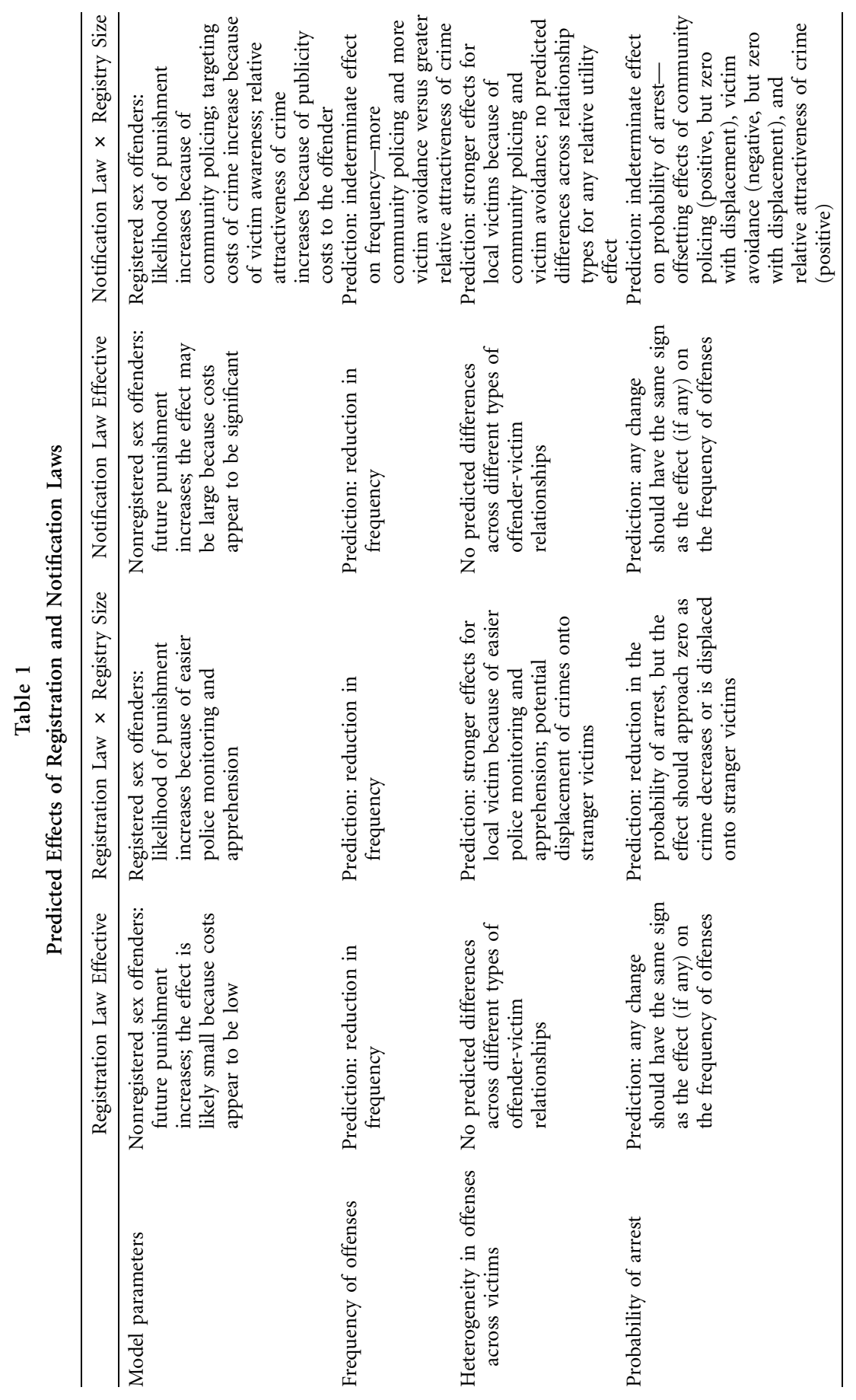


only in the 1990s, and only a subset of states participate in the program. In 1995, which was 1 year after the federal government required that states create sex offender registries and 1 year before it required that registry information be made public, there were just nine NIBRS states. By 1998, eight more states had joined the program. By 2004, a total of 30 states were collecting NIBRS data. Our analysis focuses on the 15 states that were participating in NIBRS by 1998: Colorado, Connecticut, Idaho, Iowa, Kentucky, Massachusetts, Michigan, Nebraska, North Dakota, Ohio, South Carolina, Texas, Utah, Vermont, and Virginia. ${ }^{23}$ Third, within each state, the number of reporting agencies (hereafter, ORIs, referring to the originating agency identifiers used by NIBRS to uniquely identify each of its law enforcement data sources) generally increases over time. We include ORI fixed effects in all of our regressions to account for the growth in the number of reporting agencies over time and to control for any persistent heterogeneity in ORI characteristics. ${ }^{24}$

In NIBRS, multiple offenses may be reported in a single incident, and so we classify an incident as a sex offense if any of the reported offenses falls into one of three sex offense categories: rape and sexual assault, sexual molestation ("forcible fondling" in NIBRS), or other nonviolent sex offenses (incest and statutory rape). ${ }^{25}$ We characterize the varied relationships between victims and offenders by dividing offenders into three groups based on the intimacy of their relationship with the victim: close, near, and stranger. The close group includes family members, significant others, and friends; the near group includes neighbors, acquaintances, and offenders who are otherwise known to the victim; and the stranger group includes offenders described as strangers and offenders whose relationship to the victim was not known by the victim (which is distinct from "missing" in the data).

Table 2 shows summary statistics for the sample of incidents that we examine. ${ }^{26}$ For purposes of comparison, we also include NIBRS information on ordinary

\footnotetext{
${ }^{23}$ These states are geographically diverse, but we lack data from the far West (for example, California) and the deep South (for example, Mississippi). Tennessee and West Virginia also joined NIBRS in 1998. Both had passed registration and notification laws by that time, however, so we did not include them.

${ }^{24}$ Although NIBRS surveys reporting agencies (or ORIs) on a monthly basis, an ORI may not submit a complete accounting of incidents each month. We exerted considerable effort, a full description of which is given in the Appendix, to ensure that our results are not driven by reporting errors.

${ }^{25}$ Incidents of non-sex-related crimes are used in our analysis to control for time-varying factors that may cause changes in crime rates in an ORI over time. We use ordinary assaults and other crimes as measures of violent crime reasonably similar to sex offenses and of the overall crime rate, respectively. We classify an incident as an assault if at least one of the offenses was an assault but none of the offenses was a sex offense. This latter condition affected a small number of incidents: only .3 percent of incidents with a sex offense also involved an assault, and just .02 percent of assaults also included a sex offense. By definition, incidents of other crimes do not contain a sex offense or an ordinary assault.

${ }^{26}$ Additional details are presented in Table A3, which provides summary statistics for the aggregated (to the ORI-month level) NIBRS data, the legal data, and the county and state demographic data that we use in most of our empirical work. The samples in Table A3 are identical to the data used in the regression analyses reported in Tables 3,4 , and 6.
} 
Table 2

Summary Statistics for Reported Crime Incidents

\begin{tabular}{|c|c|c|}
\hline & Sex Offenses & Assaults \\
\hline Incidents in sample & 328,260 & $4,757,118$ \\
\hline Rape and sexual assault (\%) & 37.9 & N.A. \\
\hline Forced fondling (\%) & 41.8 & N.A. \\
\hline Other nonviolent sex offenses (\%) & 20.3 & N.A. \\
\hline Incidents with report date $(\%)$ & 18.9 & 12.8 \\
\hline Incidents leading to arrest (\%) & 25.7 & 37.3 \\
\hline Average days to arrest & 24.3 & 13.7 \\
\hline Prosecution drops charges $(\%)$ & 7.1 & 4.8 \\
\hline Victim refuses to cooperate (\%) & 5.1 & 6.6 \\
\hline \multicolumn{3}{|l|}{ Offender-victim relationship (\%): } \\
\hline Immediate family & 11.5 & 24.9 \\
\hline Extended family & 9.3 & 3.7 \\
\hline Stepfamily & 4.7 & 1.3 \\
\hline Friend & 7.0 & 2.8 \\
\hline Significant other & 8.0 & 17.6 \\
\hline Acquaintance & 31.0 & 23.7 \\
\hline Neighbor & 2.4 & 1.8 \\
\hline Otherwise known & 9.6 & 9.3 \\
\hline Stranger & 8.4 & 9.7 \\
\hline Relationship unknown & 11.8 & 10.2 \\
\hline Missing relationship information & 4.3 & 4.5 \\
\hline \multicolumn{3}{|l|}{ Victim characteristics $(\%)$ : } \\
\hline Female & 86.5 & 58.4 \\
\hline White & 77.6 & 68.2 \\
\hline Black & 17.9 & 28.3 \\
\hline Age $0-4$ & 8.7 & .7 \\
\hline Age 5-9 & 14.8 & 1.6 \\
\hline Age 10-14 & 27.1 & 6.9 \\
\hline Age $15-19$ & 23.8 & 15.3 \\
\hline Age 20-29 & 13.1 & 30.2 \\
\hline Age 30-39 & 7.2 & 24.0 \\
\hline Age $40-49$ & 3.6 & 14.5 \\
\hline Age 50-65 & 1.1 & 5.6 \\
\hline Age $65+$ & .5 & 1.3 \\
\hline \multicolumn{3}{|l|}{ Offender characteristics (\%): } \\
\hline Male & 95.9 & 76.8 \\
\hline White & 69.0 & 61.5 \\
\hline Black & 24.1 & 33.9 \\
\hline Age 0-9 & 2.3 & .5 \\
\hline Age 10-14 & 11.2 & 6.2 \\
\hline Age 15-19 & 20.1 & 15.9 \\
\hline Age $20-29$ & 25.5 & 31.3 \\
\hline Age 30-39 & 20.5 & 25.4 \\
\hline Age $40-49$ & 12.0 & 14.5 \\
\hline Age 50-65 & 6.5 & 5.1 \\
\hline Age $65+$ & 1.9 & .9 \\
\hline
\end{tabular}

Note. The sample includes all sex offenses and assaults reported in 15 National IncidentBased Reporting System states (Colorado, Connecticut, Idaho, Iowa, Kentucky, Massachusetts, Michigan, Nebraska, North Dakota, Ohio, South Carolina, Texas, Utah, Vermont, and Virginia). Relationships total more than 100 percent because some incidents involved more than one relationship. N.A. = not applicable. 
assaults. Assaults are more common than sex offenses, with more than 14 assaults occurring for every sex offense. Reporting of incident dates, arrest rates, and time until arrest is quite different for the two types of crime. The frequency with which incident dates are not reported (and for which only a report date is available) is higher for sex offenses. Arrests are less common for sex offenses, and the time to arrest-conditional on the arrest occurring at least 1 day after the incident-is considerably longer.

The relationships between offenders and victims are similar for sex offenses and assaults, with family members and acquaintances as the two most common categories of offenders. The overall fraction of (reported) incidents with an acquaintance is somewhat higher for sex offenses, but sex offense incidents are less common between all family members ( 26 versus 30 percent) and significant others. For both sex offenses and ordinary assaults, the victim claimed that the offender was a stranger or that the relationship to the offender was unknown in approximately 20 percent of incidents.

Assaults and sex offenses differ significantly in terms of victim demographic characteristics. Although 51 percent of sex offense victims in our sample were younger than 15 years old, the corresponding figure for assault victims is only 9 percent. Sex offense victims are also more likely to be female and white. Offender characteristics also differ across the two types of offenses. The age distribution of sex offenders is wider than it is for people who commit assault, with larger fractions of total offenders in both the youngest and oldest age groups. Sex offenders are also much more likely to be male and somewhat more likely to be white.

Finally, we classify each incident by the registration and notification laws in effect and by the number of registered offenders on the date that the crime took place. When analyzing data aggregated to the ORI-month level, our legal variables (including information about the public availability of a state's Internet registry) reflect the law on the 15th day of the calendar month. Complete historical data on the size of registries are unavailable (particularly for early years), but we have gathered extensive information on state registry sizes at many points in time and on county registry sizes at a single point in time. Under the assumption that registries grew smoothly once established, we use these data to estimate how registry sizes evolved during our sample period. We provide details about this estimation procedure in the Appendix.

\section{Crime Frequency and Relationship Mix Results}

We estimate the effects of registration and notification laws on sex offense frequency and on the mix of offender-victim relationships using the empirical approach outlined in Section 3. All regressions include ORI, year, and month fixed effects as well as controls for annual per capita income, unemployment levels, poverty rates, and the fraction of the population in five ethnicity categories 
and 5-year age categories at the county level. In addition, we test the sensitivity of our estimates to the inclusion of the number of ordinary assaults and the number of other crimes committed per 10,000 people. We view these two controls as proxies for ORI-specific time-varying factors that influence crime rates and may be correlated with our legal variables of interest. Although we do not report the estimated coefficients for these controls, both assault rates and other crime rates are always positively related to sex offense rates, and both relationships are highly statistically significant. ${ }^{27}$

The registry indicator signifies that the state has an active offender registry, and registry size is measured using our empirical estimates, as explained in the Appendix. ${ }^{28}$ Although registry laws are fairly uniform, notification laws can be categorized into three broad types: requiring public access to a paper registry, making an Internet registry publicly available, or mandating active community notification. Within these categories, we focus on statutes that imply the "full" availability of sex offender information, which means that access was not subject to the discretion of local authorities and that the public could obtain information about local offenders in general, rather than being limited to inquiries about specific people. Full Internet availability indicates that the Internet registry was online and substantially complete. ${ }^{29}$ Full active notification denotes a law that affirmatively requires the government to deliver specific sex offender information either to the offender's neighbors or to local media for publication. Figure 2 shows the timing of the effective dates of these laws. In the regressions presented

\footnotetext{
${ }^{27}$ Including assaults and other crimes as controls for time-varying unobservable factors in our regressions may be problematic if the frequency of either set of offenses is itself affected by registration or notification laws, which could happen, for example, if assaults or other crimes are substitutes or complements to sex offenses in the eyes of offenders, in terms of the decision to commit crimes, or in the eyes of victims, in terms of whether and how to report crimes. However, we present our findings from specifications with and without these controls in Table 3, and their inclusion has little influence on our results. A complete set of results without assault rates or other crime rates included as covariates is available from the authors upon request.

${ }^{28}$ Internet and active notification laws do not necessarily apply to all registered sex offenders. In our sample, as of 2008, seven of the 15 states that we study listed 100 percent of their registered offenders on their Internet registries, and 10 listed more than 95 percent of their registered offenders. However, five states (Colorado, Iowa, Massachusetts, Nebraska, and North Dakota) listed significantly less than 95 percent of their public Internet registries. Overestimating the number of registered offenders who are subject to a certain notification provision should affect only our estimates of the coefficient on the interaction with registry size of that notification provision, and, if anything, the overestimate should bias these results toward zero (making our estimates a lower bound). To verify this logic, we ran regressions using a rough proxy-the ratio of individuals on a state's Internet registry to the total number of sex offenders registered in that state as of 2008-to construct a separate registry size for the interactions with Internet availability and active notification. As predicted, our initial estimates grew in magnitude and retained similar statistical significance levels. These results are available from the authors upon request.

${ }^{29}$ We located news articles suggesting that the Internet registries in seven states were incomplete when they were launched-that is, missing information on a significant share of the offenders required to be listed. For five of these states, we discovered sources indicating when the Internet registry was complete, was expected to be complete, or was expected to be virtually complete. Where we have an indication of incompleteness but no notice of completion (two states), we consider the Internet registry complete 3 months after launch or our last evidence of incompleteness.
} 


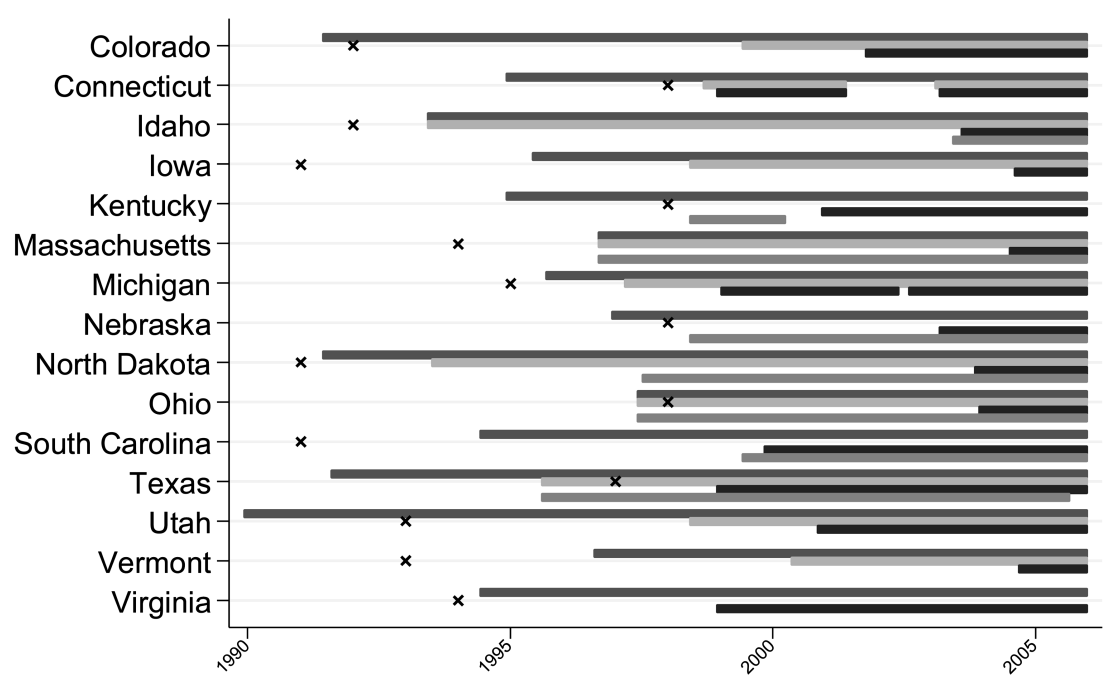

Registration Effective
Active Notification

Figure 2. Effective dates of registration and full notification laws in 15 early National Incident-Based Reporting System (NIBRS) states.

below, we define a notification law as being in effect if at least one of these full versions of notification is in place and operative. ${ }^{30}$

The unit of observation in our analysis is an ORI-month cell, and the dependent variable is measured as the annualized number of incidents per 10,000 people covered by the ORI (we multiply the monthly incident rates by 12 for ease of interpretation). ${ }^{31}$ The regressions are weighted by ORI population coverage so that the coefficients reflect average changes in crime risk faced by a typical person covered by the NIBRS sample and to account for likely hetero-

${ }^{30}$ One complication of this approach is that two states in our sample (Texas and Ohio) had registration and at least one full notification law in place before the start of their NIBRS data periods. As a consequence, these states do not contribute to the identification of the effects of these laws on the behavior of nonregistered sex offenders. Eliminating these states from our analysis, however, has little effect on our results. We report findings from a limited 13-state sample in Table A4.

${ }^{31}$ Studies of crime frequency often examine the natural log of crime as an outcome (Shao and $\mathrm{Li}$ 2006); however, this transformation is problematic in our case because we use monthly data from areas of limited size, and therefore we have many ORI-month observations with no sex offenses. Nevertheless, for comparison purposes, we also estimate regressions in which the dependent variable is the natural log of offenses plus one per 10,000 people. The results of the two specifications are alike in sign and significance. The similarity of the results is not surprising given that we weight our analysis by covered population and so rely more on more heavily populated areas that are less likely to have months without the occurrence of at least one sex offense. 
Table 3

Effects of Registration and Notification on Sex Offense Frequency

\begin{tabular}{|c|c|c|c|c|}
\hline & \multicolumn{2}{|c|}{$\begin{array}{c}\text { Sex Offenses } \\
\text { per } 10,000 \text { People }\end{array}$} & \multicolumn{2}{|c|}{$\begin{array}{c}\ln (\text { Sex Offenses } \\
\text { per } 10,000 \text { People })\end{array}$} \\
\hline & (1) & $(2)$ & (3) & (4) \\
\hline Registry Effective & $\begin{array}{l}.405 \\
(.362) \\
{[.29]}\end{array}$ & $\begin{array}{l}.362 \\
(.439) \\
{[.43]}\end{array}$ & $\begin{array}{l}.032 \\
(.029) \\
{[.30]}\end{array}$ & $\begin{array}{l}.029 \\
(.033) \\
{[.40]}\end{array}$ \\
\hline Registry Effective $\times$ Registry Size & $\begin{array}{c}-.081 \\
(.034) \\
{[.04]}\end{array}$ & $\begin{array}{c}-.098 \\
(.04) \\
{[.03]}\end{array}$ & $\begin{array}{c}-.006 \\
(.003) \\
{[.05]}\end{array}$ & $\begin{array}{c}-.007 \\
(.003) \\
{[.03]}\end{array}$ \\
\hline Notification & $\begin{aligned} &-1.155 \\
&(.369) \\
& {[.01] }\end{aligned}$ & $\begin{array}{c}-1.171 \\
\quad(.406) \\
{[.02]}\end{array}$ & $\begin{array}{c}-.078 \\
(.028) \\
{[.02]}\end{array}$ & $\begin{array}{c}-.079 \\
(.029) \\
{[.02]}\end{array}$ \\
\hline Notification $\times$ Registry Size & $\begin{array}{l}.079 \\
(.029) \\
{[.02]}\end{array}$ & $\begin{array}{l}.082 \\
(.032) \\
{[.03]}\end{array}$ & $\begin{array}{l}.006 \\
(.002) \\
{[.03]}\end{array}$ & $\begin{array}{l}.006 \\
(.002) \\
{[.04]}\end{array}$ \\
\hline Controls for assaults and other crimes & No & Yes & No & Yes \\
\hline $\begin{array}{l}\text { Mean offense frequency } \\
\text { SD }\end{array}$ & $\begin{array}{l}9.17 \\
9.70\end{array}$ & & & \\
\hline $\begin{array}{l}\text { Mean registry size } \\
\text { SD }\end{array}$ & $\begin{array}{l}15.97 \\
11.18\end{array}$ & & & \\
\hline$R^{2}$ & .35 & .36 & .68 & .68 \\
\hline
\end{tabular}

Note. The unit of observation is a reporting agency (ORI)-month cell. Registry Size is empirically estimated from registry data and is measured as the number of offenders per 10,000 people. Notification laws represent full access by the public to information on offenders. All regressions control for county income and demographics and ORI, year, and month fixed effects and are weighted by the covered population in each ORI. Bootstrapped standard errors are in parentheses, and $p$-values are in brackets. $N=210,209$.

skedasticity. ${ }^{32}$ Finally, because our sample includes a small number of states and our registry size variable is empirically estimated, using customary ordinary least squares estimates of standard errors or even clustering by state can lead to incorrect statistical inferences (Donald and Lang 2007; Cameron, Gelbach, and Miller 2008; Murphy and Topel 1985). To correct our standard errors for both of these problems, we use a bootstrap procedure we describe in the Appendix.

Table 3 reports the estimated effects of registration and notification on the frequency of sex offenses. We find no evidence that registries deter nonregistered sex offenders. In fact, the estimated impact of a new (empty) sex offender registry on the frequency of sex offenses is positive, although imprecisely measured. We do find evidence, however, that requiring registration reduces recidivism, presumably by increasing monitoring, and therefore increasing the likelihood of

\footnotetext{
${ }^{32}$ To illustrate the heteroskedasticity issue, suppose we have two ORIs, each with 10 sex offenses per 10,000 people in a given month, but one ORI has 1,000 people and another has 100,000. These two values correspond roughly to the 5th and 95th percentile of the covered population among ORIs in our sample. The smaller ORI in this example had only one actual sex offense in that month, and its sex offense rate would drop to 0 per 10,000 people if there were no crimes the following month (which is quite likely to happen given sampling variation). By contrast, the large ORI had 100 sex offenses during the month and is much less likely to drop to a rate of 0 per 10,000 people because of sampling error.
} 
punishment that potential recidivists face. Specifically, the estimated coefficient for Registry Size is negative and statistically significant, as predicted by our model. The data in column 2 of Table 3 imply that each additional sex offender registered per 10,000 people reduces the annual number of sex offenses reported per 10,000 people by .098 crime. This is a substantial reduction (1.07 percent) that, if accurate, supports placing information about sex offenders in the hands of local law enforcement in order to combat recidivism.

Notification laws also appear to affect the overall frequency of sex offenses, but the pattern of results presented in Table 3 does not correspond to the predictions furnished by proponents of notification. The estimated effect of the existence of a notification law on the number of offenses is negative and statistically significant. If our identifying assumptions are correct, the data in column 2 suggest that notification laws reduce the frequency of crime by 1.17 crimes per 10,000 people per year (approximately 12.8 percent) by deterring individuals who are not currently registered as sex offenders. ${ }^{33}$ However, the estimate for the interaction of Notification and Registry Size is positive and statistically significant. In the context of our model, this finding implies that any beneficial effect of registration on recidivism is dampened by the use of notification, and it signals that the punitive aspects of notification laws may have perverse consequences. Specifically, a basic trade-off may exist: whereas some nonregistered or potential offenders may be deterred by the threat of notification and its associated costs, the ex post imposition of those sanctions on convicted offenders may make them more likely to recidivate. ${ }^{34}$

Assuming that our evidence is accurate and our interpretation is valid, how should a legislature approach this trade-off between deterrence and recidivism? For a simple back-of-the-envelope analysis, imagine a state that must decide whether to enact a registration law, whether to enact a notification law, and how many offenders should be covered by these laws. We find that the threat of registration has a statistically insignificant positive effect on the number of annual

\footnotetext{
${ }^{33}$ Under the assumption that the passage of a law may not be well known, we use the effective dates of these laws to estimate the deterrence effects of registration and notification. In a separate analysis, we use enactment dates to estimate these deterrence effects and effective dates only to estimate the consequences of these laws for recidivism. The intuition behind this approach is that once these laws are enacted, the commission of a sex offense by a potential offender may subject him to registration and/or notification requirements in the future because, if caught, he is unlikely to be released or even convicted until after the date on which the law becomes effective. With respect to recidivism, however, these laws have to be operative to work as intended. Our results, it turns out, are not sensitive to this distinction.

${ }^{34}$ Another possible explanation for the increase in crime frequency associated with an increase in registry size is that either the authorities or the public become overwhelmed with the number of offenders as the registry grows. This strikes us as unlikely. First, with respect to the police, we continue to see a reduction in the number of offenses as the registry grows under a registration regime, which suggests that, although large registries are surely costly, police are not being overwhelmed to the point that an additional registrant reduces the overall effectiveness of the system. Second, notification regimes are primarily local. Therefore, most of the increase in registry rolls amounts to an increase from no registered offenders to two or three in a neighborhood. Citizens are not expected to track thousands of offenders, and, indeed, notification systems are not designed to work that way.
} 
sex offenses (.362 offense per 10,000 people; $p=.43$ ). However, actually registering offenders (absent notification) does reduce crime. The total effect of registration with an average-size registry (approximately 16 offenders per 10,000 people) is a yearly reduction of 1.21 sex offenses per 10,000 people $(p=.07)$. On the other hand, notification laws appear to be attractive only with a small registry. Notification precludes an additional .78 sex offense per 10,000 people per year $(p=.02)$ when 4.7 offenders per 10,000 people (the 10th percentile of registry size) are registered. By contrast, adding a notification law to an existing registration requirement with an average-size registry has an insignificant positive effect on sex offense frequency (.144 sex offense per 10,000 people; $p=.65$ ), although the overall impact of both laws is still a reduction of 1.06 sex offenses per 10,000 people per year $(p=.11)$.

If a state uses both registration and notification, if we assume that registration and notification must cover the same set of offenders, and if the only criterion is the total number of sex crimes committed, then the size of a state's registry may be relatively unimportant. The positive coefficient on Notification $\times$ Registry Size is similar in magnitude to the negative coefficient on Registry Effective $\times$ Registry Size (the difference is not statistically significant), and so the two roughly offset each other. As a result, our findings do not support the claim that expanding a notification law's coverage reduces crime. Given the substantial social and individual costs of maintaining a large registry, one implication of these estimates is that states should employ narrow notification regimes in which all or most sex offenders are required to register but only a small subset are subjected to notification. ${ }^{35}$ Alternatively, states might explore substitutes that are capable of similar gains in deterrence but avoid what may be notification-related recidivism. In any event, because notification laws were enacted to reduce recidivism, our results suggest that a reconsideration of notification laws is warranted.

We also estimate regressions in which we disaggregate our previously singular notification measure into three different types of notification regimes-full public access to paper registries, full Internet registry availability, and full active notification. ${ }^{36}$ As one would expect, this disaggregation produces less precise estimates, and yet the basic pattern of results does not change. The coefficients for all three types of notification laws and their interactions with Registry Size have the same signs (negative main effects and positive interaction effects), and the standard errors are too large to reject the hypothesis that these different approaches yield identical outcomes. Nevertheless, it is worth noting that the main effect of active notification is appreciably larger in magnitude, which implies

\footnotetext{
${ }^{35}$ One-third of the states in our sample do not apply their most stringent notification requirements to all registered sex offenders. Unfortunately, our empirical strategy prevents us from saying anything about whether these states are closer to a crime-minimizing mix of sex offender policies. Of course, in the context of our model, limited application of stringent notification provisions may not only reduce recidivism, but may weaken any deterrence effects as well.

${ }^{36}$ These results are available from the authors upon request.
} 
Table 4

Effects of Registration and Notification on Sex Offense Frequency and Relationship Mix, by Offense Type

\begin{tabular}{|c|c|c|c|c|}
\hline & $\begin{array}{l}\text { All } \\
(1)\end{array}$ & $\begin{array}{c}\text { Close } \\
(2)\end{array}$ & $\begin{array}{l}\text { Near } \\
(3)\end{array}$ & $\begin{array}{c}\text { Stranger } \\
\text { (4) }\end{array}$ \\
\hline Registry Effective & $\begin{array}{l}.362 \\
(.439) \\
{[.43]}\end{array}$ & $\begin{array}{l}.017 \\
(.189) \\
{[.93]}\end{array}$ & $\begin{array}{l}.195 \\
(.187) \\
{[.32]}\end{array}$ & $\begin{array}{c}-.088 \\
(.183) \\
{[.64]}\end{array}$ \\
\hline Registry Effective $\times$ Registry Size & $\begin{array}{c}-.098 \\
(.040) \\
{[.03]}\end{array}$ & $\begin{array}{c}-.025 \\
(.023) \\
{[.30]}\end{array}$ & $\begin{array}{c}-.041 \\
(.014) \\
{[.02]}\end{array}$ & $\begin{array}{l}.008 \\
(.011) \\
{[.48]}\end{array}$ \\
\hline Notification & $\begin{array}{c}-1.171 \\
(.406) \\
{[.02]}\end{array}$ & $\begin{array}{c}-.360 \\
(.142) \\
{[.03]}\end{array}$ & $\begin{array}{c}-.343 \\
(.146) \\
{[.04]}\end{array}$ & $\begin{array}{c}-.273 \\
(.143) \\
{[.08]}\end{array}$ \\
\hline Notification $\times$ Registry Size & $\begin{array}{l}.082 \\
(.032) \\
{[.03]}\end{array}$ & $\begin{array}{l}.022 \\
(.014) \\
{[.13]}\end{array}$ & $\begin{array}{l}.030 \\
(.013) \\
{[.04]}\end{array}$ & $\begin{array}{l}.013 \\
(.006) \\
{[.06]}\end{array}$ \\
\hline $\begin{array}{l}\text { Mean offense frequency } \\
\text { SD }\end{array}$ & 9.17 & $\begin{array}{l}3.46 \\
5.58\end{array}$ & $\begin{array}{l}3.78 \\
5.67\end{array}$ & $\begin{array}{l}1.83 \\
3.47\end{array}$ \\
\hline Mean registry size & 15.97 & 15.97 & 15.97 & 15.97 \\
\hline $\mathrm{SD}$ & 11.18 & 11.18 & 11.18 & 11.18 \\
\hline$R^{2}$ & .36 & .20 & .21 & .29 \\
\hline
\end{tabular}

Note. The unit of measurement for the dependent variables is the annualized number of incidents per 10,000 people, and the unit of observation is a reporting agency (ORI)-month cell. Registry Size is empirically estimated from registry data and is measured as the number of offenders per 10,000 people. Notification laws represent full access by the public to information on offenders. All regressions control for rates of assault and other crimes, county income and demographics, and ORI, year, and month fixed effects. Each regression is weighted by the covered population in each ORI. Bootstrapped standard errors are in parentheses, and $p$-values are in brackets. $N=210,209$.

greater deterrence of nonregistered offenders. This result makes sense, as active notification is perhaps the most intrusive form of notification and therefore may have particular deterrence value.

In Table 4, we investigate whether registration and notification laws change the incidence of sex offenses across victim types or, closely related, the equilibrium mix of offender-victim relationships. As we described above, notification laws are intended to help individuals identify and avoid involvement with convicted sex offenders who live or work nearby, and registration laws are supposed to reduce crime by providing local police with detailed information about convicted sex offenders living in their jurisdictions. To evaluate the success of these laws at reducing recidivism, and to probe the consistency between any patterns we find and the relationship mix predictions of our model, we examine whether (as lawmakers had hoped) sex offender legislation results in fewer crimes against victims who might be unaware of nearby convicted sex offenders or who are otherwise especially at risk because of their proximity to these offenders, and whether these laws leave crime against other victim types unaffected or perhaps more prevalent (as a result of crime displacement).

The NIBRS offender-victim relationship variable has one geographic element (the offender was a neighbor) but is otherwise organized by the level of familiarity 
that the victim has with the offender (for example, the offender was a friend or acquaintance) or by family ties (for example, the offender was a spouse or sibling). We use these categories to create three types of sex offenses-close (involving family members, significant others, and friends), near (involving neighbors, acquaintances, or offenders otherwise known), and stranger crimesthat our model predicts should or may respond in distinct ways to registration or notification. With respect to notification, potential victims who are neighbors or acquaintances seem more likely to learn from and respond to an offender's information being made public than do family members (although perhaps not in every case-for instance, consider a stepparent) or strangers. Thus, a reduction in recidivism due to notification should be visible in the frequency of near offenses. Similarly, registrants may be more easily monitored around their families and in their neighborhoods and more easily located when a nearby crime occurs. Therefore, registration seems more likely to reduce the number of close as well as near offenses.

The results of our relationship analysis support these conjectures and reaffirm our interpretation of Table 3. Table 4 indicates that large registries (without notification) appear to decrease crimes against victims of the close and near offense groups but not crimes against strangers. The estimate for victims of near sex offenses $(-.041)$ is highly significant $(p=.02)$, whereas the estimate for victims of close sex offenses is slightly smaller in absolute value $(-.025)$ and is not statistically significant at conventional levels $(p=.30)$. The estimate for victims of stranger sex offenses is, in contrast, small and positive (.008). These findings are consistent with the idea that registering sex offenders with law enforcement reduces crime against local victims. Registration does not appear to protect strangers, but it also does not appear to make them more likely to be victimized through displacement, as some critics have feared. ${ }^{37}$

Any deterrence of nonregistered sex offenders by registration and notification laws should not, according to our model, alter the existing offender-victim relationship mix of sex offenses. In line with this prediction, Table 4 shows no discernable deterrence effect of registration requirements for any relationship type and a similar negative effect of notification laws that is roughly comparable in percentage terms across all types.

Our model provides ambiguous predictions for how the effects of notification on recidivism by registered offenders might vary across different types of victims. If notification laws make targeting local victims more costly for a registered sex offender (increasing $c_{i j}$ ), then we should observe fewer victims of near sex offenses but a smaller reduction or even an increase in frequency (if there is displacement) of stranger crimes. Alternatively, if notification laws instead primarily make life outside of prison less attractive for sex offenders (amplifying the relative utility

\footnotetext{
${ }^{37}$ We also conducted an analysis that disaggregates offenses involving close relationships into family offenses and nonfamily offenses (namely, crimes committed by significant others and friends). The results for both groups were similar in sign and statistical significance to the results for all close relationship crimes and are available from the authors upon request.
} 
Table 5

Effects of Registration and Notification on Arrest Outcomes

\begin{tabular}{|c|c|c|c|c|}
\hline & $\begin{array}{l}\text { Arrest } \\
\text { Made } \\
(1)\end{array}$ & $\begin{array}{c}\text { Time } \\
\text { to Arrest } \\
\text { (in Days) } \\
\text { (2) }\end{array}$ & $\begin{array}{l}\text { Victim } \\
\text { Refuses } \\
\text { to Cooperate } \\
\text { (3) }\end{array}$ & $\begin{array}{c}\text { Prosecution } \\
\text { Drops } \\
\text { Charges } \\
(4)\end{array}$ \\
\hline Registry Effective & $\begin{array}{l}.0028 \\
(.0378) \\
{[.94]}\end{array}$ & $\begin{array}{c}-1.2475 \\
(1.8300) \\
{[.51]}\end{array}$ & $\begin{array}{l}.0174 \\
(.0133) \\
{[.22]}\end{array}$ & $\begin{array}{l}.0474 \\
(.0170) \\
{[.02]}\end{array}$ \\
\hline Registry Effective $\times$ Registry Size & $\begin{array}{c}-.0012 \\
(.0056) \\
{[.84]}\end{array}$ & $\begin{array}{l}.0380 \\
(.1229) \\
{[.76]}\end{array}$ & $\begin{array}{c}-.0010 \\
(.0012) \\
{[.39]}\end{array}$ & $\begin{array}{c}-.0048 \\
(.0024) \\
{[.08]}\end{array}$ \\
\hline Notification & $\begin{array}{c}-.0190 \\
(.0329) \\
{[.58]}\end{array}$ & $\begin{array}{c}.8886 \\
(2.1316) \\
{[.69]}\end{array}$ & $\begin{array}{c}-.0204 \\
(.0145) \\
{[.19]}\end{array}$ & $\begin{array}{c}-.0004 \\
(.0213) \\
{[.99]}\end{array}$ \\
\hline Notification $\times$ Registry Size & $\begin{array}{l}.0032 \\
(.0035) \\
{[.38]}\end{array}$ & $\begin{array}{c}-.0695 \\
(.1099) \\
{[.54]}\end{array}$ & $\begin{array}{l}.0019 \\
(.0011) \\
{[.11]}\end{array}$ & $\begin{array}{l}.0038 \\
(.0023) \\
{[.14]}\end{array}$ \\
\hline $\begin{array}{l}\text { Mean of dependent variable } \\
\text { SD }\end{array}$ & .23 & $\begin{array}{l}15.81 \\
23.89\end{array}$ & .07 & .10 \\
\hline $\begin{array}{l}\text { Mean registry size } \\
\text { SD }\end{array}$ & $\begin{array}{l}15.36 \\
10.14\end{array}$ & $\begin{array}{r}14.57 \\
9.69\end{array}$ & $\begin{array}{l}15.36 \\
10.14\end{array}$ & $\begin{array}{l}15.36 \\
10.14\end{array}$ \\
\hline$N$ & 287,789 & 65,702 & 287,789 & 287,789 \\
\hline$R^{2}$ & .10 & .12 & .10 & .14 \\
\hline
\end{tabular}

Note. The unit of observation is a reported sex offense. Registry Size is empirically estimated from registry data and is measured as the number of offenders per 10,000 people. Notification laws represent full access by the public to information on offenders. In column 2, the sample is restricted to reported sex offenses that resulted in arrests. All regressions include controls for victim and offender characteristics, victimoffender relationship, type of sex offense, and reporting agency (ORI), year, and month fixed effects. Bootstrapped standard errors are in parentheses, and $p$-values are in brackets.

of crime commission), crime might increase as the registry grows, and if notification laws do not alter the relative cost of attacking certain victims, any increase should be spread equally across all types of victims. Table 4 favors this latter scenario. The estimate for the interaction of Notification and Registry Size is positive and statistically significant across all groups, and, in percentage terms, the estimated increases are very close to each other. Thus, although notification may serve as a deterrence to nonregistered offenders, prompting local victims to protect themselves against registered offenders may do little to reduce recidivism - and may in fact increase it.

The estimated effects of registration and notification laws on our arrest and criminal processing variables for all sex offenses are shown in Table $5 .^{38}$ Although

\footnotetext{
${ }^{38}$ For analysis of arrests and dropped cases, as noted in Section 3, we examine incident-level data instead of ORI-month aggregates. We also drop the controls for assaults and other crimes (which are aggregate statistics) and include incident-specific variables in addition to victim and offender age, sex, and ethnicity indicators; indicators for the type of offender-victim relationship; indicators for the number of victims and the number of offenders (capped at four); and indicators for the type of sex offense (rape and sexual assault, sexual molestation, and other nonviolent sex offenses). We include this broad set of covariates to control as best we can for the information available to law enforcement authorities and to examine law enforcement performance conditional on this information.
} 
the point estimates in column 1 are consistent with the predictions in Section 3 , no statistically significant relationship exists between whether an arrest is made and any of the legal change and enforcement variables. Therefore, if the decrease in crime associated with registering convicted sex offenders is indeed caused by an increased probability of punishment, the response by the offenders to this new probability must eliminate (in equilibrium) any visible change in the arrest probability and, likewise, in the time to arrest. The coefficients on the notification variables on the likelihood an arrest is made show the same pattern. The threat of being subjected to notification may reduce the number of crimes, but it does not appear to increase the equilibrium probability of arrest. The estimate for the interaction of Notification and Registry Size is positive, as would be predicted by a change in crime due to a relative utility effect, but statistically insignificant and very imprecisely estimated. ${ }^{39}$

At a minimum, our analysis provides evidence to support those who argue that registration and notification laws matter to the frequency of reported sex offenses. Registration laws seem to reduce recidivism, especially against the neighbors and acquaintances of registered offenders, and notification laws appear to deter those potential offenders who can still avoid notification's psychological and financial costs by refraining from committing qualifying sex offenses. More tentatively, however, our results also raise the possibility that notification laws make returning to criminal behavior more attractive to registered sex offenders by subjecting them to public ridicule and social isolation, perhaps leading them to commit additional sex offenses.

\section{Robustness Checks}

Here we address possible concerns about our interpretation and the reliability of our empirical estimates. First, we explore whether unobserved variables or trends may account for the relationships we find by ascertaining whether similar empirical associations exist between sex offender laws and crimes other than sex offenses. We also examine the robustness of our basic specification and sample choice. Second, we consider whether our results, especially those that are consistent with a relative utility effect, might be driven by changes in victim reporting

\footnotetext{
${ }^{39}$ With respect to dropped cases, we find little evidence that victim noncooperation is associated with registration and notification. However, we do discover suggestive evidence that a prosecutor's decision to decline a case occurs more frequently in areas with a small registry but less frequently as the size of the registry grows, at least until the advent of notification in the state. These results are plausible. Prosecutions may suffer at the start of a registration regime, as police personnel are used and criminal justice resources are spent on the construction and introduction of the registry. However, as the number of registered offenders increases, police may have access to more and better information about local offenders, which leads to stronger average cases. Later, with the arrival of notification, prosecutors may find that the advantages of registration information to the state become degraded when community members also have this information, perhaps because of false accusations, a possibility we discuss in Section 6. The evidence here, however, allows only speculation.
} 
behavior. We cannot completely rule out this possibility, but we present findings that seem inconsistent with a reporting-behavior explanation.

\subsection{Falsification Tests and Specification Checks}

The relationships we identify may be spurious if unobservable factors that influence crime levels also happen to be correlated with the passage of registration and notification laws or with changes in registry size. To increase our confidence that registration and notification are causally related to sex offender behavior, we repeat our analysis using as outcomes the overall frequency of other types of crimes-crimes that we believe are far less likely to be affected by the criminal behavior of individuals who are on the margin of committing or recommitting sex offenses. These placebo test estimates ought to reveal no statistically significant relationships between the implementation of these laws and non-sex-related crime frequencies. ${ }^{\mathbf{4 0}}$

We examine auto theft, drug offenses, fraud, weapons violations, forgery, and larceny. These crimes are quite different from rape and child molestation, and our intuition is that they are neither substitutes for nor complements to sex offenses, even though a few of them occur with roughly similar frequency. Of the 24 coefficients that we estimate, we find only two statistically significant relationships between the reported rates of these six crimes and our four registration and notification variables (a pattern that might easily occur randomly), and neither of these estimates lines up with our sex offense results. ${ }^{41}$ Furthermore, the inconsistent signs and small magnitudes of all of the placebo coefficients increase our confidence that our earlier results are not confounded by general trends in crime. To illustrate, five of the six estimated coefficients on Registry Size are actually positive. ${ }^{42}$

Another concern, especially when working with data from relatively few states

\footnotetext{
${ }^{40}$ We note that any relative utility effect generated by sex offender notification might cause registered sex offenders to commit other crimes as well. Therefore, these placebo tests should not be viewed as falsification checks in the usual sense, because finding positive relationships between Notification $\times$ Registry Size and non-sex-related crime frequencies is consistent with our model. Still, we purposefully selected comparison crimes that are very different from sex offenses to reduce the likelihood that changes in the behavior of registered sex offenders would show up in the overall frequencies of these crimes. Admittedly, released sex offenders do commit many types of crimes. For example, among all sex offenders released in 16 states in 1994, subsequent arrests for auto theft occurred half as frequently as arrests for another sex offense (authors' calculations performed using data from U.S. Department of Justice [2007]). However, although released sex offenders are far more likely than other released criminals to be arrested for sex offenses, they are considerably less likely to be arrested for the crimes that we consider here. Furthermore, released sex offenders constitute a relatively small portion of all released criminals, which makes any portion of placebo crimes committed by sex offenders small.

${ }^{41}$ For weapons offenses, we find a borderline statistically significant negative coefficient on the indicator for whether a registry is effective, but recall that we find no evidence that the existence of a registry alone has any effect on sex offense frequency (and our estimated coefficient is actually positive). Registry Size is also significantly correlated $(p=.05)$ with the number of larcenies, but that correlation is positive, the opposite of what we find for sex offenses.

${ }^{42}$ These results and the other robustness findings that we describe throughout Section 6 are available from the authors upon request.
} 
in a quasi-experimental setting as our empirical strategy does, is that haphazard changes in one large state might plausibly account for all of our key results (see Currie and MacLeod 2007). For each state in our sample, we verify the robustness of our findings to this possibility by reestimating equation (2) on a subsample that only contains data from the other states we study. Our results are not sensitive to these exclusions.

Our analysis controls for ORI, month, and year fixed effects, local economic and demographic characteristics, and contemporaneous crime trends, but it remains possible that our empirical strategy attributes the consequences of some unknown trend to our registration and notification variables. Up to this point, we have not included state-specific trends in our analysis because one of our variables of interest-Registry Size-closely approximates a state trend (see Figure A1). By partialling out state-specific linear trends, therefore, we effectively discard important information in an attempt to address possible but ultimately hypothetical omitted variables. Still, even though we view our earlier specification as more appropriate, incorporating state-level linear trends can be informative in this context by showing that alternative accounts for our findings are less likely to be true.

In Table 6, we present our original results along with results from specifications that include state-specific linear trends. Our findings are fairly robust to the inclusion of these trends. In column 3 , the magnitude of the main notification effect decreases but remains marginally statistically significant. ${ }^{43}$ The coefficient on Registry Size is also smaller and less precisely estimated but reasonably similar in magnitude relative to our previous specifications. In column 6, we report estimates from a log-linear specification with state-specific linear trends, including a coefficient on Registry Effective $\times$ Registry Size that is similar in magnitude and statistical significance to our baseline estimate in column 5 . The estimated coefficient on Notification $\times$ Registry Size remains positive and highly statistically significant in every column, regardless of the specification. Overall, controlling for linear state-specific trends does not change the overall picture and suggests that unobservable state trends are unlikely to explain the results in Table 3.

Equation (2) assumes that the effects of registration and notification laws on registered sex offender behavior (but not on nonregistered offender behavior) increase linearly with registry size. This premise might be incorrect for at least two reasons. First, notification regimes with very large registries might overwhelm potential victims, making comprehensive notification laws less useful to the public than smaller-scale versions. Second, a large registry might dramatically

\footnotetext{
${ }^{43}$ It is worth pointing out that the coefficient on Notification is statistically significant at the 5 percent level in Table A4, where we restrict our sample to the 13 states that actually passed a notification statute during our sample period. With the addition of state-specific linear trends as controls, Table A4's estimate of the deterrence effects of notification may be more accurate because it makes less sense to include, as we do in Table 6, the two states (Texas and Ohio) for which there is no legal variation in registration and full notification in our data.
} 
Table 6

Robustness of Registration and Notification Effects on Sex Offense Frequency

\begin{tabular}{|c|c|c|c|c|c|c|}
\hline & \multicolumn{3}{|c|}{$\begin{array}{l}\text { Sex Offenses per } \\
10,000 \text { People }\end{array}$} & \multicolumn{3}{|c|}{$\begin{array}{l}\ln (\text { Sex Offenses per } \\
10,000 \text { People })\end{array}$} \\
\hline & (1) & (2) & (3) & (4) & (5) & (6) \\
\hline Registry Effective & $\begin{array}{l}.405 \\
(.362) \\
{[.29]}\end{array}$ & $\begin{array}{l}.362 \\
(.439) \\
{[.43]}\end{array}$ & $\begin{array}{c}-.132 \\
(.323) \\
{[.69]}\end{array}$ & $\begin{array}{l}.032 \\
(.029) \\
{[.30]}\end{array}$ & $\begin{array}{l}.029 \\
(.033) \\
{[.40]}\end{array}$ & $\begin{array}{c}-.004 \\
(.025) \\
{[.87]}\end{array}$ \\
\hline Registry Effective $\times$ Registry Size & $\begin{array}{c}-.081 \\
(.034) \\
{[.04]}\end{array}$ & $\begin{array}{c}-.098 \\
(.040) \\
{[.03]}\end{array}$ & $\begin{array}{c}-.065 \\
(.035) \\
{[.09]}\end{array}$ & $\begin{array}{c}-.006 \\
(.003) \\
{[.05]}\end{array}$ & $\begin{array}{c}-.007 \\
(.003) \\
{[.03]}\end{array}$ & $\begin{array}{c}-.005 \\
(.002) \\
{[.05]}\end{array}$ \\
\hline Notification & $\begin{array}{c}-1.155 \\
(.369) \\
{[.01]}\end{array}$ & $\begin{array}{c}-1.171 \\
\quad(.406) \\
{[.02]}\end{array}$ & $\begin{array}{c}-.511 \\
(.315) \\
{[.14]}\end{array}$ & $\begin{array}{c}-.078 \\
(.028) \\
{[.02]}\end{array}$ & $\begin{array}{c}-.079 \\
(.029) \\
{[.02]}\end{array}$ & $\begin{array}{c}-.027 \\
(.025) \\
{[.30]}\end{array}$ \\
\hline Notification $\times$ Registry Size & $\begin{array}{l}.079 \\
(.029) \\
{[.02]}\end{array}$ & $\begin{array}{l}.082 \\
(.032) \\
{[.03]}\end{array}$ & $\begin{array}{l}.050 \\
(.016) \\
{[.01]}\end{array}$ & $\begin{array}{l}.006 \\
(.002) \\
{[.03]}\end{array}$ & $\begin{array}{l}.006 \\
(.002) \\
{[.04]}\end{array}$ & $\begin{array}{l}.004 \\
(.001) \\
{[.02]}\end{array}$ \\
\hline Controls for assaults and other crimes & No & Yes & Yes & No & Yes & Yes \\
\hline State linear trends & No & No & Yes & No & No & Yes \\
\hline $\begin{array}{l}\text { Mean offense frequency } \\
\text { SD }\end{array}$ & $\begin{array}{l}9.17 \\
9.70\end{array}$ & & & & & \\
\hline $\begin{array}{l}\text { Mean registry size } \\
\text { SD }\end{array}$ & $\begin{array}{l}15.97 \\
11.18\end{array}$ & & & & & \\
\hline$R^{2}$ & .35 & .36 & .36 & .68 & .68 & .68 \\
\hline
\end{tabular}

Note. The unit of observation is a reporting agency (ORI)-month cell. Registry Size is empirically estimated from registry data and is measured as the number of offenders per 10,000 people. Notification laws represent full access by the public to information on offenders. All regressions control for county income and demographics and ORI, year, and month fixed effects and are weighted by the covered population in each ORI. Bootstrapped standard errors are in parentheses, and $p$-values are in brackets. $N=210,209$.

overextend police resources, making registration and notification less effective (and even counterproductive), at least once a registry reaches some threshold size. We believe that these effects are unlikely to matter significantly in practice. The world is not teeming with registered sex offenders. The maximum registry size in our sample is less than 40 sex offenders per 10,000 people, for example, while the average number of police in the United States during this period was approximately 20 per 10,000 people (Evans and Owens 2007).

Nevertheless, we explore these concerns with a specification identical to equation (2), except for the inclusion of two new quadratic terms in registry size:

$$
\begin{aligned}
\text { Crime }_{j t}= & \alpha_{j}+\gamma_{t}+\lambda X_{j t} \\
& +\sum_{s} D_{j}^{s}\left[\beta_{0} \mathbf{R g}_{t}^{s}+\beta_{1} \mathbf{N t}_{t}^{s}+\left(\beta_{2} \mathbf{R g}_{t}^{s}+\beta_{3} \mathbf{N t}_{t}^{s}\right) \times \mathrm{RgSize}_{j t}\right] \\
& +\sum_{s} D_{j}^{s}\left[\left(\beta_{4} \mathbf{R g}_{t}^{s}+\beta_{5} \mathbf{N t}_{t}^{s}\right) \times \operatorname{RgSize}_{j t}^{2}\right]+\varepsilon_{j t} .
\end{aligned}
$$

This exercise demonstrates that our linear specifications are more appropriate. The quadratic coefficient estimates $\left(\beta_{4}\right.$ and $\left.\beta_{5}\right)$ are extremely small in magnitude and statistically insignificant, which signifies that their inclusion in the model 
is unnecessary. In any event, our findings in equation (4) for the main effects of registration and notification and the linear interactions with registry size are actually significantly greater in magnitude, although they are understandably less precisely estimated than our estimates in Table 3.

\subsection{Reporting Behavior}

Like most studies of criminal behavior, we can only examine the frequency of reported crime, not actual crime, and so it is possible that our findings are affected or driven by changes in victim reporting behavior. Reporting is a decidedly important issue for the study of sex offenses-data from the National Crime Victimization Survey indicate that less than 50 percent of rape and sexual assault victimizations are reported to the police (Rennison 2002)_-and especially for the study of laws that are designed to influence the behavior of potential sex offense victims.

Sex offender notification laws, in particular, may reduce reporting by victims who have a personal relationship with an offender or who consider notification to be an overly harsh new punishment (Iyengar 2009). Alternatively, victims may eschew reporting because notification may reveal (or be more likely to reveal) to friends and coworkers their status as victims. Yet these very plausible stories seem unlikely to fully account for our results, given the effects that we find for neighbor and acquaintance offenses and given that we find a decrease in crime associated with registration alone. ${ }^{44}$ Registration and notification may also cause offenders to move away from family, friends, and acquaintances to avoid the accompanying shame or other burdens of these laws. Thus, reduced contact with registered offenders might explain a reduction in the frequency of offenses against these groups. However, it seems more likely a priori that this type of mechanical change in the relationship mix of reported offenses would be more important for notification than for registration, a possibility that is at odds with our findings. Finally, a notification law could reduce the frequency of sex offenses, regardless of the number of registered offenders, if the law increases awareness of sex offenses in general and makes all potential victims more cautious. We cannot test this hypothesis directly, but it necessarily assumes that registration and notification laws influence more than just reporting behavior, and our model could accommodate this reaction with a broader notion of deterrence.

By contrast, changes in victim reporting behavior appear at first glance more than adequate to explain our finding that broad notification regimes with large

\footnotetext{
${ }^{44}$ Changes in reporting behavior may also generate an underestimate of any crime-reducing effects of registration. For example, if the existence of a registration system led victims to believe that reporting a crime was more likely to lead to an arrest, they might have been more likely to report crimes, increasing the measured crime rate, all else equal. Many victims either knew or learned that their state had a registry and may have assumed that any assailant was registered with positive probability. Such a dynamic could account for our positive (but statistically insignificant) coefficient on our Registry Effective variable.
} 
registries are associated with an increase in the number of sex offenses. Two changes in reporting behavior seem to be the most likely candidates. As a registry grows and law enforcement notifies an increasing number of individuals that one or more sex offenders live nearby, frivolous reporting of sex offenses might increase because the proximity of a sex offender is made known and salient to potential victims, and true reporting of crime that would otherwise have gone undetected might also increase. Both of these hypotheses are reasonable, but we find little evidence to support them in our data.

If frivolous reports of sex offenses became more common in response to more offenders being subjected to notification, holding offender behavior constant, we would expect to see either a reduction in the likelihood that a report led to an arrest (because the average case reported has, all else equal, less merit) and/ or an increase in the probability that a case was dismissed by the prosecutor because, again, the average case became weaker. In our analysis reported in Table 5 , the estimated coefficient on Notification $\times$ Registry Size is positive for the prosecutorial dismissal rate, but it is almost exactly offset by a positive coefficient of similar magnitude for the arrest rate. Furthermore, neither estimate is statistically significant. Thus, our arrest results do not support a simple frivolous reporting story as an explanation for our finding that notification regimes with large registries are associated with more sex offenses.

Another way to examine the reporting hypothesis is to study adult rape and child molestation offenses separately. Although registration and notification laws apply uniformly to rapists and child molesters, both kinds of reporting biases (frivolous reporting or meritorious reporting of previously undetected crime) seem more likely to occur in the context of molestation. Information that a sex offender lives nearby may make parents more aware of their children's behavior or whereabouts and cause parents to be more likely to investigate their suspicions than they would have been without the knowledge of a nearby sex offender. However, mere knowledge that a neighbor is a sex offender seems less likely, all else equal, to change reporting behavior substantially in the case of a rape of an adult.

When we separately investigate the effects of sex offender laws on the frequency of child molestation and forcible rape, which constitute the bulk of all sex offenses (see Table 2), using the specification in equation (2), we find no evidence of shifts in reporting behavior. If increased reporting underlies our findings, we would expect to find the Notification $\times$ Registry Size effect driven by molestation cases. Instead, we calculate very similar point estimates for both types of sex offenses: .047 for forced fondling $(p=.01)$ and .040 for forcible rape $(p=$ $.08)$. As a percentage of the mean offense frequency, the estimated coefficient is higher for child molestation than it is for rape (19.5 versus 12.8 percent), but the difference is not statistically significant. Overall, although reporting changes may explain some part of our findings, substantial evidence supports the claim that sex offenders alter their behavior in response to registration and notification laws. 


\section{Conclusion}

We examine the effect of sex offender registration and notification laws on the total frequency of sex offenses, the mix of offender-victim relationships, and law enforcement performance, conditional on the report of a sex offense. We find evidence that registration laws reduce the frequency of reported sex offenses, particularly when the number of registrants is large, and argue that therefore there may be benefits to providing information on convicted sex offenders to local authorities. We estimate that an average-size registry decreases crime by approximately 1.21 sex offenses per 10,000 people, which is a 13 percent reduction from the sample mean. This drop in crime benefits local victims (acquaintances, neighbors, and victims of known offenders, as well as possibly family members, friends, and significant others). We find no evidence that registration influences the extent of crime against strangers.

We also demonstrate that notification laws may affect sex offense frequency, albeit not necessarily as lawmakers intended. We estimate that notification laws reduce the number of sex offenses when the size of the registry is small but that these benefits dissipate as more offenders become subject to notification requirements. This pattern is consistent with notification deterring nonregistered individuals but encouraging recidivism among registered offenders, perhaps because of the social and financial costs associated with the public release of their criminal history and personal information. When a registry is of average size, adding a notification regime effectively increases the number of sex offenses by more than 1.57 percent.

Although researchers are still in the process of measuring the benefits of registration and notification laws, the costs have been well documented. A number of scholars have established the financial, physical, and psychological damage to registered sex offenders and their families (Zevitz and Farkas 2000a; Tewksbury 2005; Levenson and Cotter 2005). The labor and capital costs to law enforcement agencies that are required to monitor offenders can also be substantial (Zevitz and Farkas 2000b). Moreover, there is evidence that these laws create financial and psychological costs for the neighbors of registered sex offenders. Linden and Rockoff (2008) and Pope (2008) document declines in property value for households living close to registered offenders, and several studies find little evidence that notification alleviates the concerns of the community members who have been made aware of an offender's presence (Zevitz and Farkas 2000b; Beck and Travis 2004, 2006).

The lack of empirical evidence for the recidivism-reducing benefits of registration and notification has not stopped policy makers from imposing additional restrictions on convicted sex offenders. Registration and notification laws are now, in some sense, old technology. Today, states are in the midst of imposing even more intrusive laws, such as residency restrictions and civil commitment, with fresh hope of reducing recidivism. These policies may impose even higher costs on sex offenders and their families than registration and notification laws 
have, and research is needed to understand if the effects, if any, of these policies on criminal behavior makes these investments worthwhile.

\section{Appendix}

\section{A1. Coding Registration and Notification Laws}

To build our database of registration and notification laws, we constructed a detailed legal timeline for each state, relying principally on paper legislative sources, legal databases containing statutes and judicial opinions, news releases and stories, and conversations and e-mail communications with state employees. We catalogued enactment dates, effective dates, and compliance dates for each legal change and verified, when possible, that such changes took place in reality and not just on paper. We cross-checked our research with other sources compiling sex offender laws and resolved all conflicts. Finally, we recorded the precise content of these legal changes, which is particularly necessary with sex offender notification laws because they differ across states on various dimensions.

As noted in Section 2, states invariably began regulating sex offenders with registration statutes that required that all information on sex offenders be kept confidential. Over time, however, state laws evolved toward making more of this information public. Most states began by providing public access to their registration databases but varied in the restrictions that they placed on access to this information. Some states (for example, Idaho) only allowed the public to make information requests in writing or about specific persons. Other states (for example, Michigan) made information available about all sex offenders in the area and allowed the public to openly inspect their registries at police departments or other government agencies. Both approaches to public access assume that potential victims or witnesses will make use of these opportunities despite their nontrivial travel and time costs. By the end of our sample period, all states maintained a functioning Internet registry, and many had enacted more active community notification laws.

\section{A2. National Incident-Based Reporting System and Demographic Data}

Many of the advantages and disadvantages of NIBRS data are described in Section 4, but we met additional challenges and made additional choices in constructing our data for analysis. One limitation is that the first year for which any state's NIBRS data are publicly available is 1995. Because some sex offender laws in the NIBRS states we study became effective before 1995, we requested additional data from the FBI, available for a few states back to 1991, and incorporated those data into our analysis. Excluding data from 1991-94 does not affect our results, however. Another complexity, discussed briefly in Section 4, is that participation of law enforcement agencies can vary within a state and over time. Agencies are identified in NIBRS by an originating agency identifier (ORI), and within each state, the number of reporting ORIs increases dramatically over time. For example, the number of reporting ORIs from Nebraska 
more than quintupled between 1998 (its first reporting year) and 2005. Consequently, we include ORI fixed effects in all of our regressions.

In building our offense variables (sex offense, assault, or other crime) and our relationship groups for crimes (close, near, and stranger), we found that a nontrivial number of sex offenses involved multiple victims ( 8 percent) or multiple offenders ( 8 percent). Therefore, the indicators we created to capture the relationship between the offender and the victim include all offender-victim relationships. For example, if an offender commits a crime against two victims, a family member and a friend of the offender, both the family member and friend indicators are set equal to one. In a separate analysis, we recorded only the closest offender-victim relationship, and the results of our analysis do not change. When we examine arrest and other process outcomes, we account for individual-level victim and offender characteristics with information from the first victim and first offender listed if the incident involves multiple victims or multiple offenders.

In addition to the NIBRS information on victims, offenders, and arrestees, our regressions also employ annual, county-level demographic data from the U.S. census on the proportion of the population in 18 age-by-sex categories and five ethnicities, as well as annual county-level data on income per capita, poverty rates, and unemployment rates. Although some ORIs are smaller than counties, we believe that these are the best annual data available to control for any demographic shifts that may have occurred within ORIs over our sample period. For the 2 percent of ORIs that are located in multiple counties, we use a weighted average of county characteristics based on the population of the ORI in each county.

\section{A3. Addressing Reporting Errors in the National Incident-Based Reporting System}

We use a multifaceted approach to handle reporting errors in the NIBRS data that we use. First, we use the indicators provided in NIBRS for whether an ORI reported crime in a given month. Among ORIs reporting crime during any month of each year, the fraction reporting for all 12 months ranged from 68 percent in 1995 to 89 percent in 2004 . We limit our analysis to crimes that took place during months when the ORI reported crime in the previous month, the current month, and the next 4 months. This restriction causes us to exclude less than 5 percent of the sex offenses that occurred between February 1991 and August 2005, and all offenses occurring outside of this period.

Despite this initial cleaning of the data, we found many instances of apparent underreporting of crimes by the agencies included in NIBRS. For example, an agency might report approximately 500 crimes every month for many months, report few or no crimes for 1 month, and then return to the previous pattern of 500 crimes per month. We also discovered agencies that, according to the 


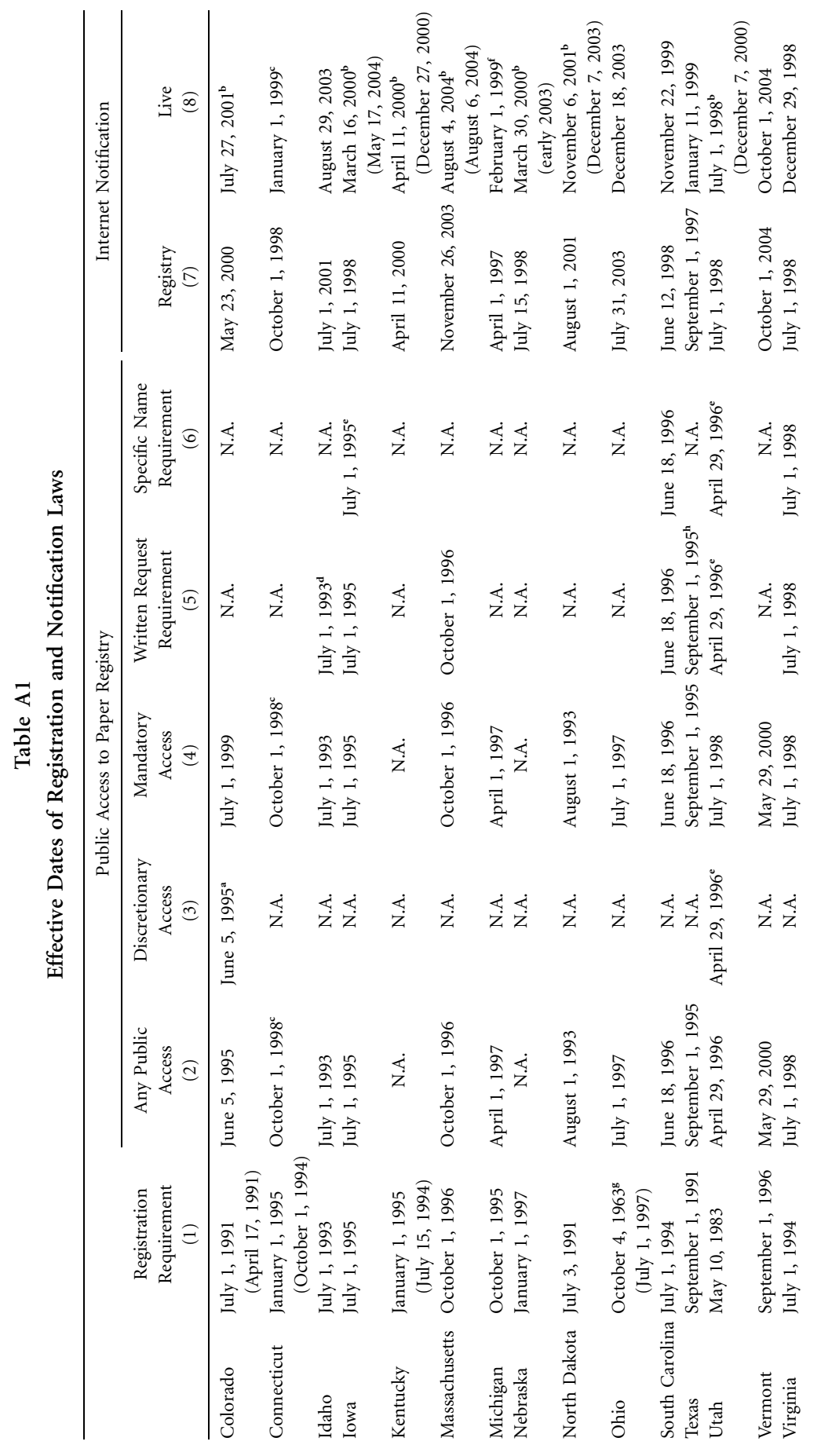




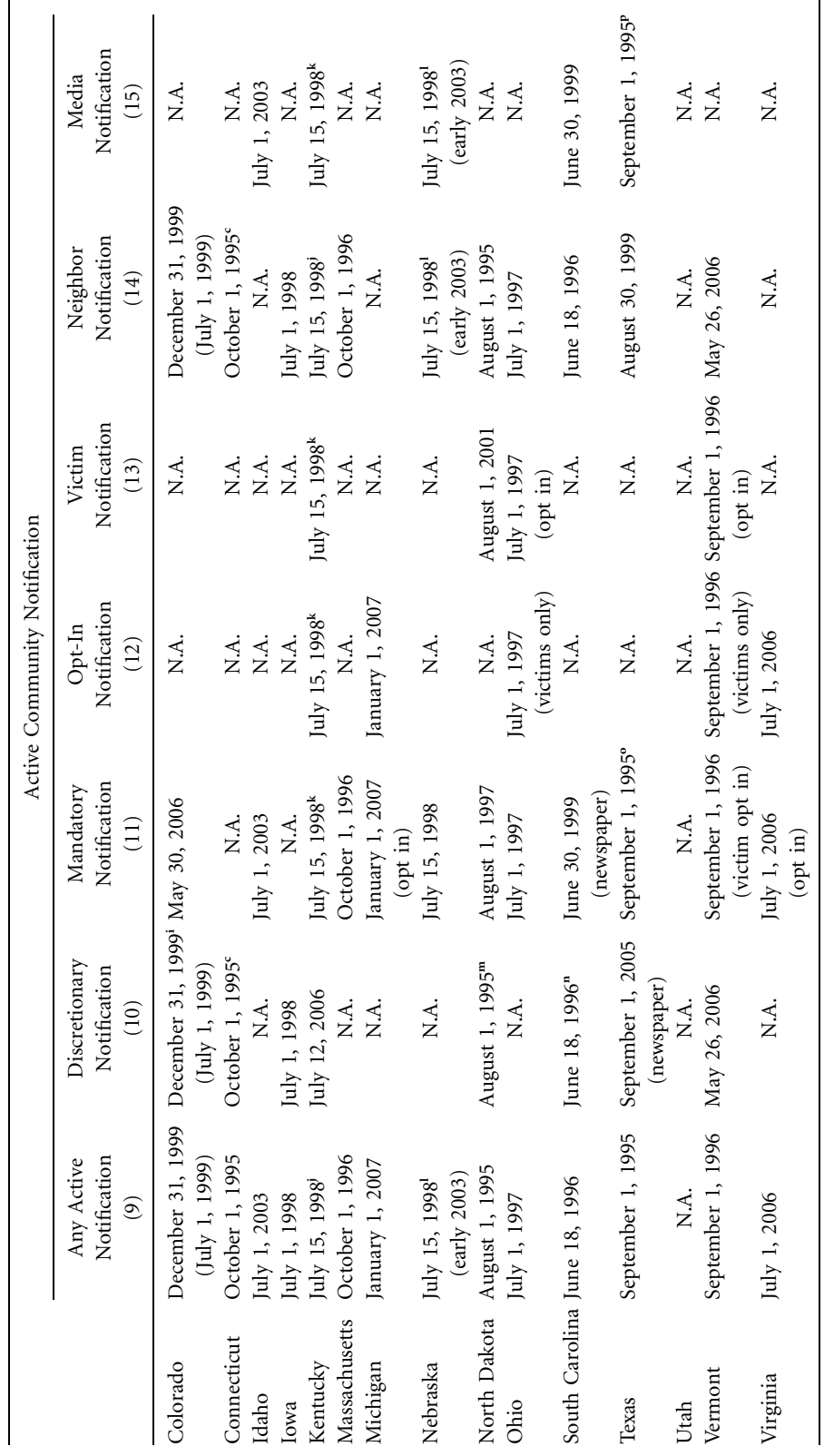




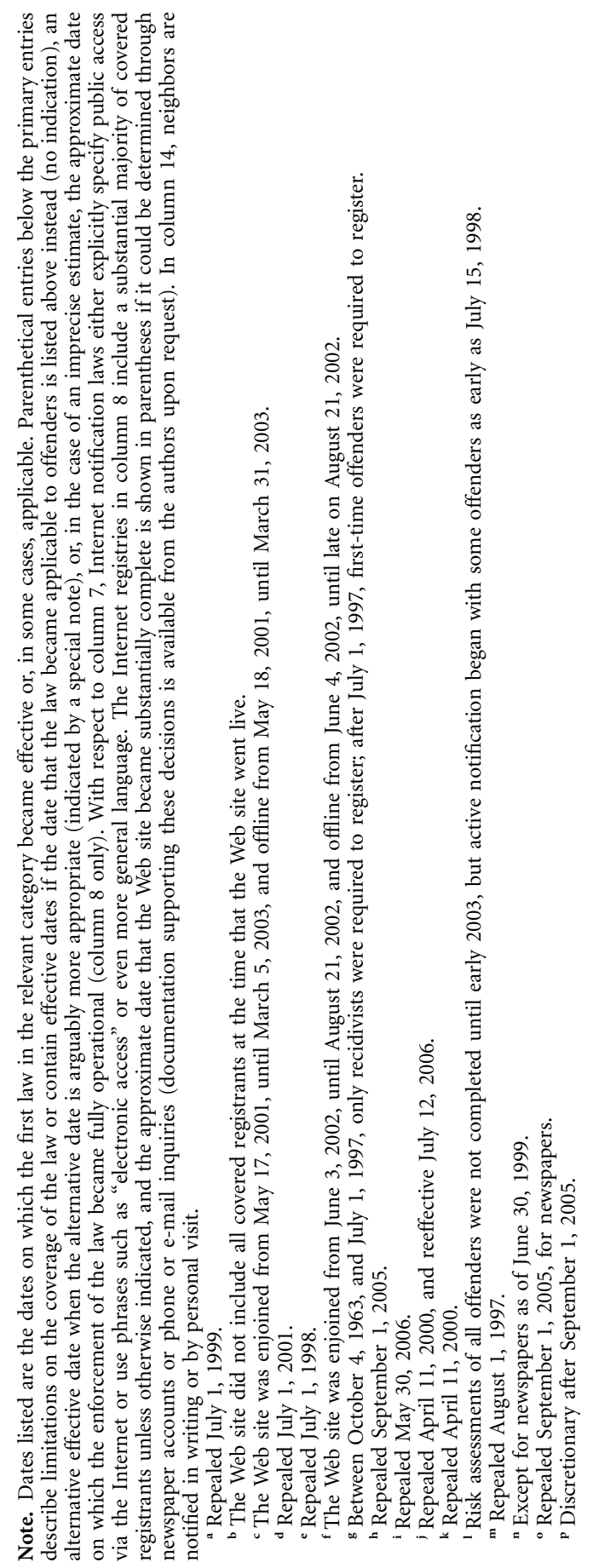




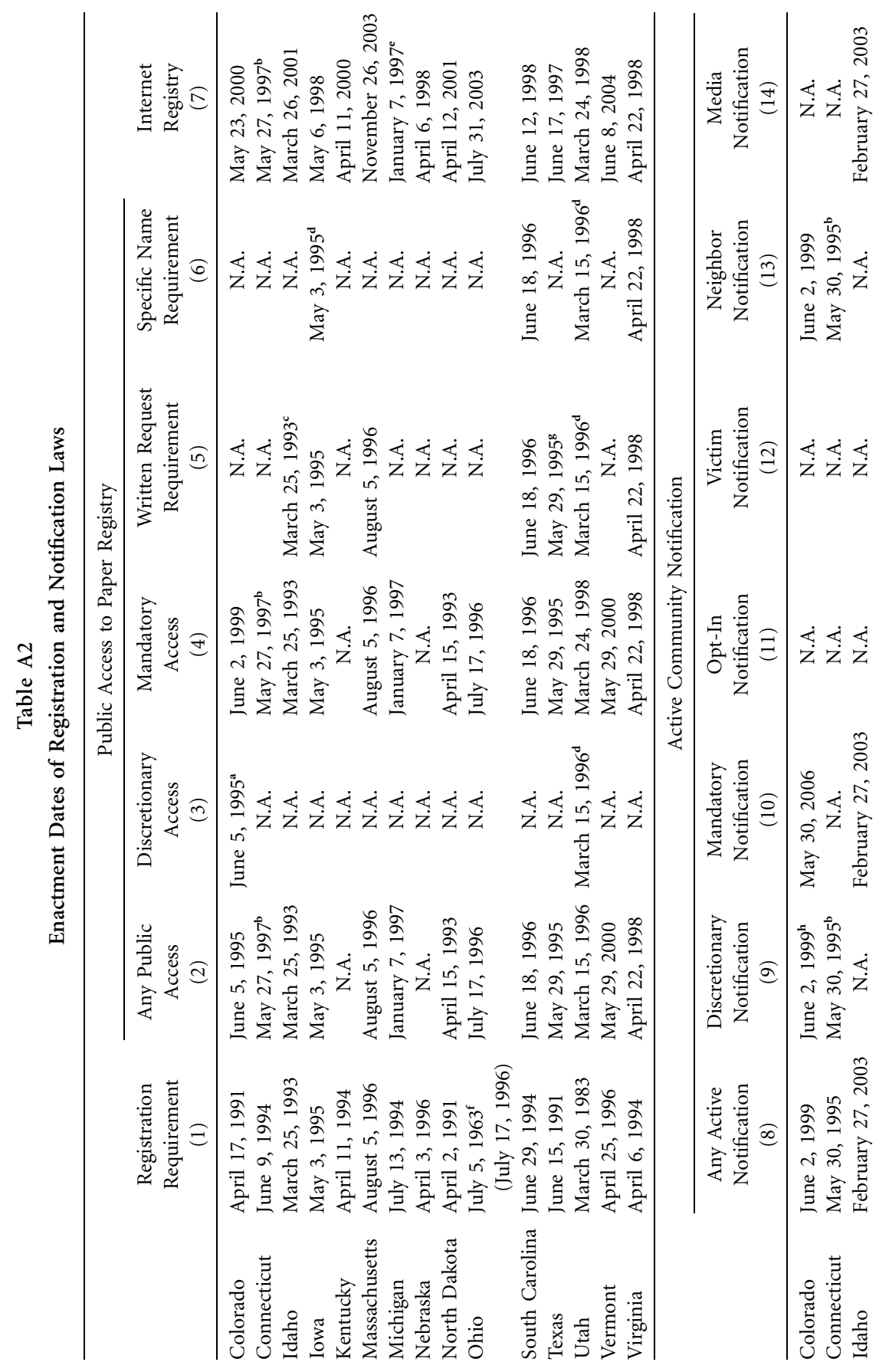




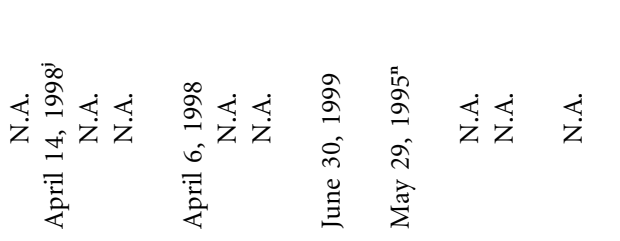

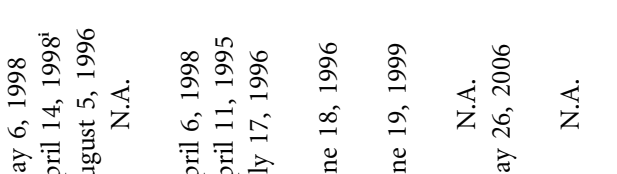

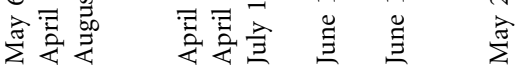

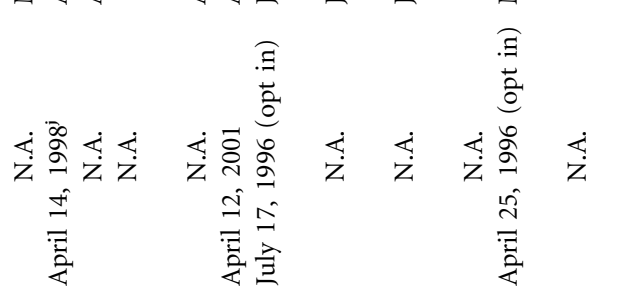

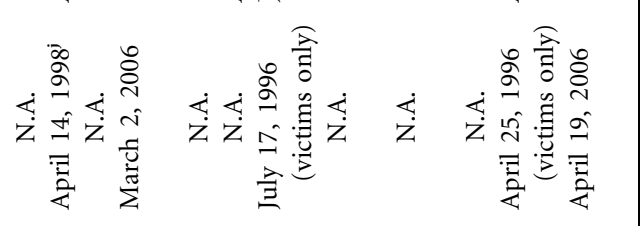

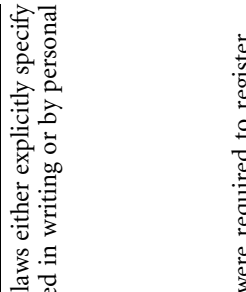

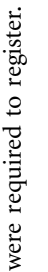

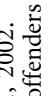

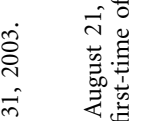

ปี

$\sum$ 西

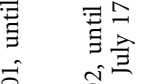

ठั่ ठำ

$\stackrel{0}{\infty} \quad \hat{\tilde{W}}$

苯莒

㿣蛋

急芯

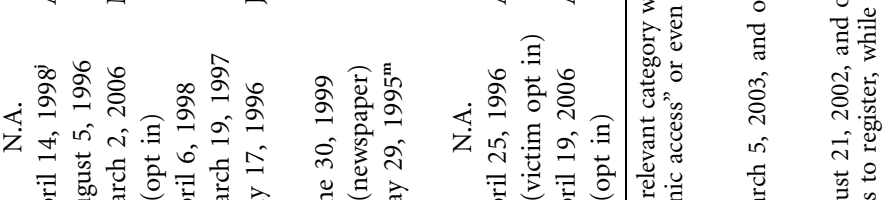

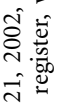

$+\frac{1}{5}$

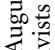

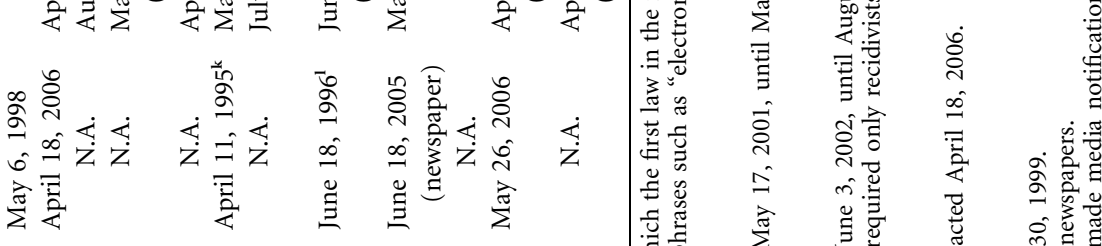

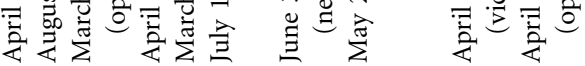

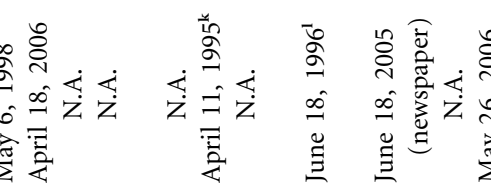

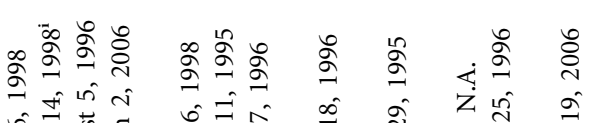

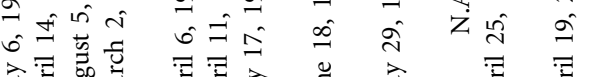

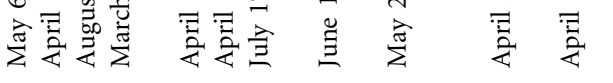

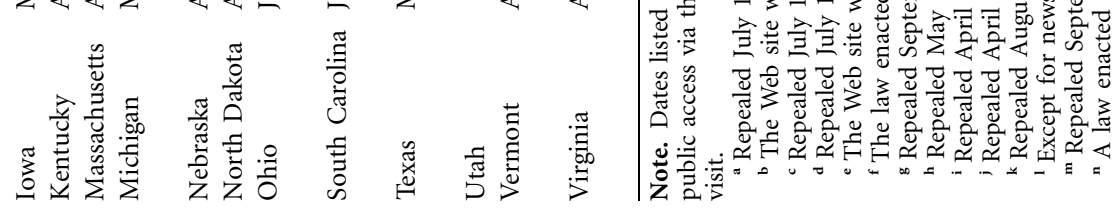


NIBRS indicator variables, started officially reporting on a given month but actually report no offenses until several months later.

We addressed this kind of misreporting by implementing an algorithm to identify these patterns and excise unreliable data. First, we took each agencyperiod cell, and we calculated the variance in the number of crimes reported over periods a given length of time from the month of that cell, and then we flagged (and later dropped) all observations that were outliers given this variance (that is, the reported number of crimes in that month had a very small chance of occurring, assuming that reports are normally distributed with given variance). We repeated this process for reports up to 6 periods away and flagged observations twice: first, those with 1 in 1 million chances of being observed and, second, those with 1 in 100,000 chances of being observed. This two-stage process is helpful because it allows us to recalculate the variance after eliminating very distant outliers. We also flagged all months adjacent to months with underreporting to guard against the possibility that underreporting in 1 month leads to overreporting in others.

\section{A4. Registry Size Estimates}

Our data on historical registry sizes come from various sources. Two reports from the National Institute of Justice provide us with state registry sizes at the end of 1998 and 2001 (Adams 2002). In addition, we gathered documents and other sources posted online by the National Center for Missing and Exploited Children that provide counts of offenders registered in each state at several points in time from 2003 through 2007. The exact dates on which the states or other organizations gathered this information vary, but, in general, these data give us a snapshot of registry sizes in 2003, 2005, 2006, and 2007. We also add data from news articles and state government reports. Finally, when possible, we make use of the fact that some states did not apply their laws retroactively and include a zero at the start of their registries.

Thus, although we collected data on the number of registered offenders in each state at multiple points in time, there are some periods for which we do not have information. To estimate the historical registry size for these NIBRS states, we ran a least-squares regression of registry size on a quadratic function of date, allowing for state-specific intercepts and slopes and using all data points available for each state. We then used the predicted values from this regression as measures of the state registry size for each month. The results of these regressions are depicted in Figure A1.

We combine this state-level information on registry size with information on all registered offenders for each county nationwide as of August 2007. Family Watchdog, a private company that provides sex offender information to the public, compiled these data and provided them to us for research purposes. ${ }^{45}$ This information allows us to calculate the number of registered sex offenders

\footnotetext{
${ }^{45}$ Family Watchdog (http://www.familywatchdog.com).
} 


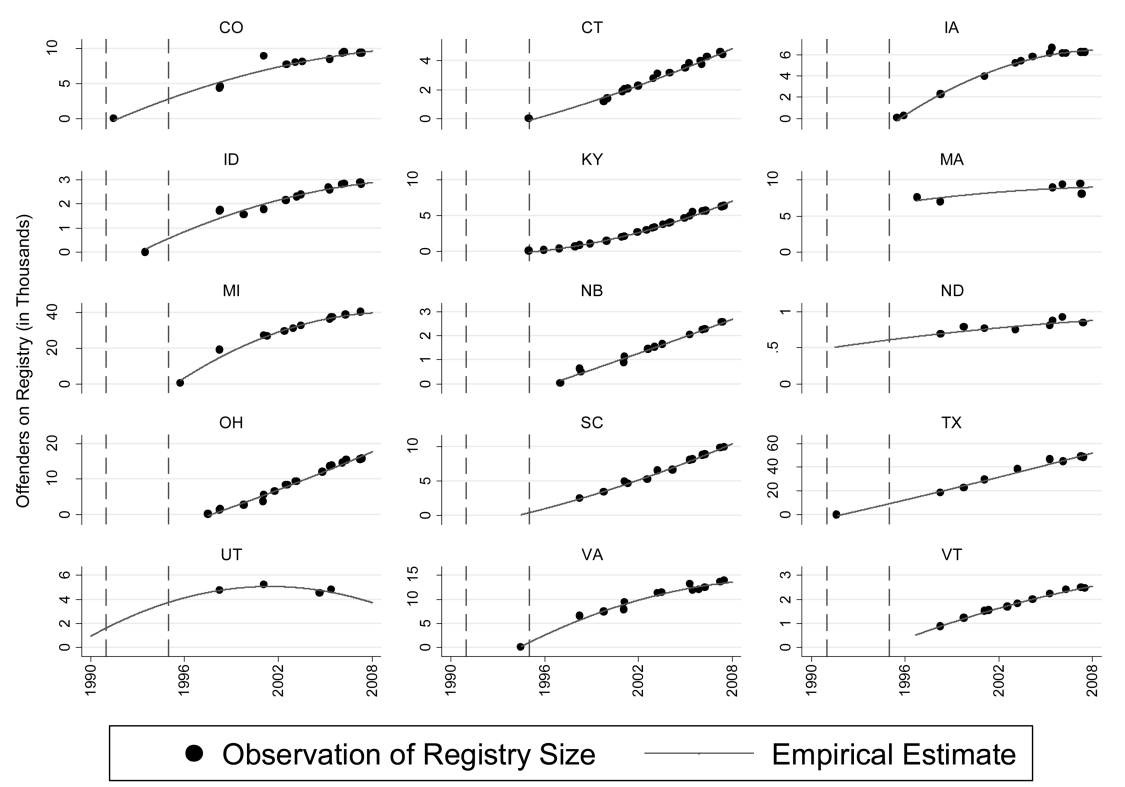

Figure A1. Observations and empirical estimates of registry sizes for 15 National IncidentBased Reporting System states.

by county in each NIBRS state in 2007. Then, for each state, we allocate our 1991-2005 estimates of the number of sex offenders on a state's registry to the state's counties using the assumption that the fraction of registered offenders by county today is reflective of the fractions in past years.

\section{A5. Bootstrap Method for Standard Error Estimates}

To estimate unbiased standard errors in the presence of a small number of clusters, we follow Cameron, Gelbach, and Miller (2008) and employ a bootstrapping methodology. Specifically, we repeat each regression in our analysis 100 times and calculate our standard errors using the variance of the resulting estimates. Let $\beta_{1}$ be the estimated vector of coefficients from repetition $i$. Our variance estimate is $\hat{\sigma}_{\beta^{*}}^{2}$, where

$$
\sigma_{\beta^{*}}^{2}=\frac{1}{N-1} \sum_{i}^{N}\left(\beta_{i}-\bar{\beta}\right)^{2}, \quad N=100 .
$$

In the simulations performed by Cameron, Gelbach, and Miller (2008), this technique, which they term "paired bootstrap-se," does not perform as well as other techniques, such as wild bootstrap, in the sense that it finds a placebo to have a statistically significant relationship with the dependent variable at the .05 level in approximately 10 percent of their simulations. However, it is not clear 
from their work whether this difference is reflective of a general result that would apply to our situation-namely, an unbalanced panel with groups of differing size and independent variables that have different variances across these groups. We find that the standard errors calculated using a wild-bootstrap procedure are smaller than those that we calculate with the paired bootstrap, and so we use the paired bootstrap estimates to be conservative.

In addition to sampling our states (with replacement) in each repetition, we take account of any additional bias that might result from our generated regressors by using registry size estimates that are calculated from values drawn randomly from the distribution of our estimator in the first stage, where we estimate registry size. Specifically, we take the estimator of the $K$ parameters from the first stage $\left(\gamma_{0}\right)$ and use the Cholesky decomposition of the variancecovariance matrix $(\boldsymbol{V})$ to draw a new vector $\left(\boldsymbol{\gamma}_{i}\right)$ where

$$
\gamma_{i}=\gamma_{0}+V^{1 / 2} R, \quad R=\left[\begin{array}{lll}
r_{1} & \ldots & r_{K}
\end{array}\right],
$$

$$
r_{i} \sim \text { independently and identically distributed } N(0,1) \text {. }
$$

We then use this vector of coefficients to reestimate registry size for each regression. 
Table A3

Summary Statistics for Reporting Agency (ORI)-Level Samples

\begin{tabular}{|c|c|c|c|c|c|c|}
\hline & \multicolumn{4}{|c|}{1991 Start } & \multicolumn{2}{|c|}{1995 Start } \\
\hline & 15 States & SD & 13 States & SD & 15 States & SD \\
\hline ORI population & 18,750 & 38,570 & 17,207 & 29,349 & 19,052 & 39,503 \\
\hline \multicolumn{7}{|l|}{$\begin{array}{c}\text { Offenses (annualized, per } \\
10,000 \text { people): }\end{array}$} \\
\hline Total sex offenses & 9.17 & 9.70 & 9.17 & 9.87 & 9.09 & 9.67 \\
\hline Rape offenses & 4.71 & 6.29 & 4.68 & 6.44 & 4.65 & 6.25 \\
\hline Forced fondling offenses & 3.85 & 5.88 & 3.91 & 6.14 & 3.83 & 5.85 \\
\hline Assaults & 138.3 & 116.0 & 135.8 & 117.5 & 136.6 & 114.9 \\
\hline Other crimes & 514.6 & 338.3 & 504.5 & 337.8 & 509.6 & 333.1 \\
\hline \multicolumn{7}{|l|}{$\begin{array}{l}\text { Registration and notification } \\
\text { laws: }\end{array}$} \\
\hline Registration effective & .928 & .26 & .904 & .30 & .984 & .13 \\
\hline Full notification effective & .790 & .41 & .721 & .45 & .847 & .36 \\
\hline Full public access effective & .580 & .49 & .513 & .50 & .620 & .49 \\
\hline \multicolumn{7}{|l|}{ Full Internet access } \\
\hline effective & .513 & .50 & .452 & .50 & .554 & .50 \\
\hline \multicolumn{7}{|l|}{ Full active community } \\
\hline notification effective & .284 & .45 & .189 & .39 & .307 & .46 \\
\hline $\begin{array}{l}\text { Registry size (estimated, } \\
\text { including states with }\end{array}$ & & & & & & \\
\hline no registry) & 14.81 & 11.53 & 14.67 & 11.75 & 15.87 & 11.22 \\
\hline \multicolumn{7}{|l|}{ ORI-level demographics: } \\
\hline \multicolumn{7}{|l|}{ Per capita personal } \\
\hline income $(\$ 1,000 \mathrm{~s})$ & 28.96 & 15.40 & 27.32 & 16.64 & 29.85 & 15.65 \\
\hline Unemployment rate & .048 & .019 & .047 & .020 & .047 & .018 \\
\hline \multicolumn{7}{|l|}{ Male: } \\
\hline Age 1-14 & .219 & .026 & .220 & .027 & .218 & 0.025 \\
\hline Age 15-29 & .218 & .043 & .218 & .045 & .217 & 0.042 \\
\hline Age $30-44$ & .232 & .025 & .231 & .024 & .231 & .025 \\
\hline Age $45-64$ & .228 & .031 & .226 & .032 & .231 & .030 \\
\hline Age $65+$ & .104 & .029 & .105 & .029 & .104 & .028 \\
\hline \multicolumn{7}{|l|}{ Female: } \\
\hline Age 1-14 & .201 & .024 & .202 & .025 & .200 & .024 \\
\hline Age $15-29$ & .202 & .041 & .203 & .043 & .201 & .041 \\
\hline Age $30-44$ & .225 & .024 & .224 & .024 & .225 & .025 \\
\hline Age $45-64$ & .229 & .030 & .227 & .031 & .232 & .028 \\
\hline Age $65+$ & .142 & .037 & .144 & .037 & .142 & .037 \\
\hline Black & .122 & .143 & .119 & .147 & .118 & .140 \\
\hline White & .798 & .149 & .815 & .144 & .798 & .148 \\
\hline Hispanic & .053 & .064 & .044 & .049 & .056 & .065 \\
\hline$N$ & 210,209 & & 172,231 & & 190,571 & \\
\hline
\end{tabular}

Note. Data are aggregated from the incident level to the ORI-month level and are weighted by the population covered by the National Incident Based Reporting System for the number of offenses, registration and notification laws, and ORI-level demographics. The size of the registry is estimated empirically using registry data and is measured as the number of offenders per 10,000 people. Mean registry size is calculated over all ORI-months, including the months when no law was in place and therefore when the registry size is zero. 
Table A4

Effects of Registration and Notification on Sex Offense Frequency: 13-State Sample

\begin{tabular}{|c|c|c|c|c|c|c|}
\hline & \multicolumn{3}{|c|}{$\begin{array}{l}\text { Sex Offenses per } \\
\text { 10,000 People }\end{array}$} & \multicolumn{3}{|c|}{$\begin{array}{l}\ln (\text { Sex Offenses per } \\
10,000 \text { People })\end{array}$} \\
\hline & (1) & (2) & (3) & (4) & (5) & (6) \\
\hline Registry Effective & $\begin{array}{l}.361 \\
(.382) \\
{[.37]}\end{array}$ & $\begin{array}{l}.297 \\
(.447) \\
{[.52]}\end{array}$ & $\begin{array}{c}-.215 \\
(.338) \\
{[.54]}\end{array}$ & $\begin{array}{l}.032 \\
(.029) \\
{[.29]}\end{array}$ & $\begin{array}{l}.029 \\
(.032) \\
{[.39]}\end{array}$ & $\begin{array}{c}-.006 \\
(.026) \\
{[.81]}\end{array}$ \\
\hline Registry Effective $\times$ Registry Size & $\begin{array}{c}-.070 \\
(.035) \\
{[.08]}\end{array}$ & $\begin{array}{c}-.087 \\
(.042) \\
{[.07]}\end{array}$ & $\begin{array}{c}-.059 \\
(.034) \\
{[.11]}\end{array}$ & $\begin{array}{c}-.006 \\
(.003) \\
{[.05]}\end{array}$ & $\begin{array}{c}-.006 \\
(.003) \\
{[.04]}\end{array}$ & $\begin{array}{c}-.005 \\
(.002) \\
{[.04]}\end{array}$ \\
\hline Notification & $\begin{array}{c}-1.118 \\
\quad(.405) \\
{[.02]}\end{array}$ & $\begin{array}{c}-1.146 \\
\quad(.402) \\
{[.02]}\end{array}$ & $\begin{array}{c}-.539 \\
(.247) \\
{[.05]}\end{array}$ & $\begin{array}{c}-.075 \\
(.028) \\
{[.02]}\end{array}$ & $\begin{array}{c}-.076 \\
(.027) \\
{[.02]}\end{array}$ & $\begin{array}{c}-.029 \\
(.018) \\
{[.13]}\end{array}$ \\
\hline Notification $\times$ Registry Size & $\begin{array}{l}.081 \\
(.03) \\
{[.02]}\end{array}$ & $\begin{array}{l}.083 \\
(.032) \\
{[.02]}\end{array}$ & $\begin{array}{l}.056 \\
(.016) \\
{[.01]}\end{array}$ & $\begin{array}{l}.006 \\
(.002) \\
{[.03]}\end{array}$ & $\begin{array}{l}.006 \\
(.002) \\
{[.03]}\end{array}$ & $\begin{array}{l}.004 \\
(.001) \\
{[.01]}\end{array}$ \\
\hline Controls for assault and other crimes & No & Yes & Yes & No & Yes & Yes \\
\hline State linear trends & No & No & Yes & No & No & Yes \\
\hline $\begin{array}{l}\text { Mean offense frequency } \\
\text { SD }\end{array}$ & $\begin{array}{l}9.17 \\
9.87\end{array}$ & & & & & \\
\hline $\begin{array}{l}\text { Mean registry size } \\
\text { SD }\end{array}$ & $\begin{array}{l}16.23 \\
11.28\end{array}$ & & & & & \\
\hline$R^{2}$ & .30 & .31 & .31 & .61 & .62 & .62 \\
\hline
\end{tabular}

Note. The unit of observation is a reporting agency (ORI)-month cell. Registry Size is empirically estimated from registry data and is measured as the number of offenders per 10,000 people. Notification laws represent full access by the public to information on offenders. All regressions control for county income and demographics and ORI, year, and month fixed effects and are weighted by the covered population in each ORI. Bootstrapped standard errors are in parentheses, and $p$-values are in brackets. $N=172,231$.

\section{References}

Adams, Devon B. 2002. Fact Sheet: Summary of State Sex Offender Registries, 2001. Bureau of Justice Statistics Special Report No. NCJ 192265. Washington, D.C.: U.S. Department of Justice.

Adkins, Geneva, David Huff, and Paul Stageberg. 2000. The Iowa Sex Offender Registry and Recidivism. Iowa Department of Human Rights, Division of Criminal and Juvenile Justice Planning and Statistical Analysis Center, Des Moines.

Agan, Amanda. 2007. Sex Offender Registries: Fear without Function? Unpublished manuscript. University of Chicago, Department of Economics, Chicago.

Bachman, Ronet, Raymond Paternoster, and Sally Ward. 1992. The Rationality of Sexual Offending: Testing a Deterrence/Rational Choice Conception of Sexual Assault. Law and Society Review 26:343-72.

Beck, Victoria Simpson, and Lawrence F. Travis III. 2004. Sex Offender Notification and Fear of Victimization. Journal of Criminal Justice 32:455-63.

- 2006. Sex Offender Notification: A Cross-State Comparison. Police Practice and Research 7:293-307. 
Becker, Gary S. 1968. Crime and Punishment: An Economic Approach. Journal of Political Economy 76:169-217.

Hart, Jordana, and Globe Staff. 1996. High-Risk Sex Offenders to be Named on TV. Boston Globe, October 5.

Cameron, Colin, Jonah B. Gelbach, and Douglas L Miller. 2008. Bootstrap-Based Improvements for Inference with Clustered Errors. Review of Economics and Statistics 90: 414-27.

Currie, Janet, and W. Bentley MacLeod. 2008. First Do No Harm? Tort Reform and Birth Outcomes. Quarterly Journal of Economics 123:795-830.

Di Tella, Rafael, and Ernesto Schargrodsky. 2004. Do Police Reduce Crime? Estimates Using the Allocation of Police Forces after a Terrorist Attack. American Economic Review 94:115-33.

Donald, Stephen G., and Kevin Lang. 2007. Inference with Difference-In-Differences and Other Panel Data. Review of Economics and Statistics 89:221-33.

Edwards, William, and Christopher Hensley. 2001. Contextualizing Sex Offender Management Legislation and Policy: Evaluating the Problem of Latent Consequences in Community Notification Laws. International Journal of Offender Therapy and Comparative Criminology 45:83-101.

Evans, William N., and Emily G. Owens. 2007. COPS and Crime. Journal of Public Economics 91:181-201.

Filler, Daniel M. 2001. Making the Case for Megan's Law: A Study in Legislative Rhetoric. Indiana Law Journal 76:315-45.

Freeman-Longo, Robert E. 1996. Prevention or Problem. Sexual Abuse: A Journal of Research and Treatment 8:91-100.

Hanson, R. Karl. 2002. Recidivism and Age: Follow-up Data from 4,673 Sexual Offenders. Journal of Interpersonal Violence 17:1046-62.

Iyengar, Radha. 2007. I'd Rather Be Hanged for a Sheep than a Lamb: The Unintended Consequences of “Three-Strikes" Laws. NBER Working Paper No. 13784. National Bureau of Economic Research, Cambridge, Mass.

- 2009. Does the Certainty of Arrest Reduce Domestic Violence? Evidence from Mandatory and Recommended Arrest Laws. Journal of Public Economics 93:85-98.

Jacob, Brian, Lars Lefgren, and Enrico Moretti. 2007. The Dynamics of Criminal Behavior: Evidence from Weather Shocks. Journal of Human Resources 42:489-527.

Kessler, Daniel, and Steven D. Levitt. 1999. Using Sentencing Enhancements to Distinguish between Deterrence and Incapacitation. Journal of Law and Economics 42:343-63.

Langan, Patrick A., and David J. Levin. 2002. Recidivism of Prisoners Released in 1994. Bureau of Justice Statistics Special Report No. NCJ 193427. Washington, D.C.: U.S. Department of Justice.

Langan, Patrick A., Erica L. Schmitt, Matthew R. Durose. 2003. Recidivism of Sex Offenders Released from Prison in 1994. Bureau of Justice Statistics Report No. NCJ 198281. Washington, D.C.: U.S. Department of Justice.

Lee, David S., and Justin McCrary. 2005. Crime, Punishment, and Myopia. NBER Working Paper No. 11491. National Bureau of Economic Research, Cambridge, Mass.

Levenson, Jill S., and Leo P. Cotter. 2005. The Effect of Megan's Law on Sex Offender Reintegration. Journal of Contemporary Criminal Justice 21:49-66.

Levenson, Jill S., and David A. D’Amora. 2007. Social Policies Designed to Prevent Sexual Violence: The Emperor's New Clothes? Criminal Justice Policy Review 18:168-99. 
Levitt, Steven D. 1998. Juvenile Crime and Punishment. Journal of Political Economy 106: 1156-85.

Lieb, Roxanne. 1996. Community Notification Laws: A Step Toward More Effective Solutions. Journal of Interpersonal Violence 11:298-300.

Linden, Leigh, and Jonah E. Rockoff. 2008. Estimates of the Impact of Crime Risk on Property Values from Megan's Laws. American Economic Review 98:1103-27.

Murphy, Kevin M., and Robert H. Topel. 1985. Estimation and Inference in Two-Step Econometric Models. Journal of Business and Economic Statistics 3:370-79.

Nagin, Daniel S. 1998. Criminal Deterrence Research at the Outset of the Twenty-First Century. Crime and Justice 23:1-42.

Pawson, Ray. 2002. Does Megan's Law Work? A Theory-Driven Systematic Review. Working Paper No. 8. Economic and Social Research Council, Centre for Evidence Based Policy and Practice, London.

Pope, Jaren C. 2008. Do Scarlet Letters Lead to Scarlet Homes? Household Reactions to Public Information from Sex Offender Registries. Working Paper No. 2008-02. Virginia Polytechnic Institute and State University, Department of Agricultural and Applied Economics, Blacksburg.

Prentky, Robert A. 1996. Community Notification and Constructive Risk Reduction. Journal of Interpersonal Violence 11:295-98.

Presser, Lois, and Elaine Gunnison. 1999. Strange Bedfellows: Is Sex Offender Notification a Form of Community Justice? Crime Delinquency 45(3):299-315.

Rennison, Callie Marie. 2002. Rape and Sexual Assault: Reporting to Police and Medical Attention, 1992-2000. NCJ 194530. Washington, D.C.: U.S. Department of Justice, Bureau of Justice Statistics.

Schram, Donna D., and Cheryl Darling Milloy. 1995. Community Notification: A Study of Offender Characteristics and Recidivism. Working Paper No. 95-10-1101. Washington State Institute for Public Policy, Olympia.

Shao, Ling, and Jing Li. 2006. The Effect of Sex Offender Registration Laws on Rape Victimization. Unpublished manuscript. University of Alabama, Department of Economics, Tuscaloosa.

Tewksbury, Richard. 2005. Collateral Consequences of Sex Offender Registration. Journal of Contemporary Criminal Justice 21:67-81.

U.S. Department of Justice. 2006. National Corrections Reporting Program, 2002 (computer file). Ann Arbor, Mich.: Inter-university Consortium for Political and Social Research (distributor).

- 2007. Recidivism of Prisoners Released in 1994 (computer file). Ann Arbor, Mich.: Inter-university Consortium for Political and Social Research.

Vásquez, Bob Edward, Sean Maddan, and Jeffery T. Walker. 2008. The Influence of Sex Offender Registration and Notification Laws In the United States: A Time Series Analysis. Crime and Delinquency 54:175-92.

Winick, Bruce J. 1998. Sex Offender Law in the 1990s: A Therapeutic Jurisprudence Analysis. Psychology, Public Policy, and Law 4:505-70.

Zevitz, Richard G., and Mary Ann Farkas. 2000a. Sex Offender Community Notification: Managing High Risk Criminals or Exacting Further Vengeance? Behavioral Sciences and the Law 18:375-91.

Zevitz, Richard G., and Mary Ann Farkas. 2000b. Sex Offender Community Notification: Assessing the Impact in Wisconsin. National Institute of Justice Report. Washington, D.C.: National Institute of Justice. 